\title{
Space and time in the tectonic evolution of the northwestern Iberian Massif: Implications for the Variscan belt
}

\author{
José R. Martínez Catalán \\ Departamento de Geología, Universidad de Salamanca, 37008 Salamanca, Spain \\ Ricardo Arenas \\ Departamento de Petrología y Geoquímica, Universidad Complutense, 28040 Madrid, Spain \\ Florentino Díaz García \\ Departamento de Geología, Universidad de Oviedo, 33005 Oviedo, Spain \\ Pablo González Cuadra \\ Área de Geodinámica Externa, Universidad de León, 24007 León, Spain \\ Juan Gómez-Barreiro \\ Jacobo Abati \\ Pedro Castiñeiras \\ Javier Fernández-Suárez \\ Sonia Sánchez Martínez \\ Pilar Andonaegui \\ Departamento de Petrología y Geoquímica, Universidad Complutense, 28040 Madrid, Spain \\ Emilio González Clavijo \\ Alejandro Díez Montes \\ Instituto Geológico y Minero de España, Azafranal 48, 37001 Salamanca, Spain \\ Francisco J. Rubio Pascual \\ Instituto Geológico y Minero de España, Ríos Rosas 23, 28003 Madrid, Spain \\ Beatriz Valle Aguado \\ Departamento de Geociências, Universidade de Aveiro, 3810-193 Aveiro, Portugal
}

\begin{abstract}
Recent advances in geochemical studies of igneous rocks, isotopic age data for magmatism and metamorphism, quantitative pressure-temperature $(P-T)$ estimates of metamorphic evolution, and structural geology in the northwestern Iberian Massif are integrated into a synthesis of the tectonic evolution that places the autochthonous
\end{abstract}


and allochthonous terranes in the framework of Paleozoic plate tectonics. Because northwestern Iberia is free from strike-slip faults of continental scale, it is retrodeformable and preserves valuable information about the orthogonal component of convergence of Gondwana with Laurentia and/or Baltica, and the opening and closure of the Rheic Ocean.

The evolution deduced for northwest Iberia is extended to the rest of the Variscan belt in an attempt to develop a three-dimensional interpretation that assigns great importance to the transcurrent components of convergence. Dominant Carboniferous dextral transpression following large Devonian and Early Carboniferous thrusting and recumbent folding is invoked to explain the complexity of the belt without requiring a large number of peri-Gondwanan terranes, and its ophiolites and highpressure allochthonous units are related to a single oceanic closure.

Palinspastic reconstruction of the Variscan massifs and zones cannot be achieved without restoration of terrane transport along the colliding plate margins. A schematic reconstruction is proposed that involves postcollisional strike-slip displacement of $\sim 3000 \mathrm{~km}$ between Laurussia and Gondwana during the Carboniferous.

Keywords: Variscan belt, exotic terranes, accretionary history, strike-slip tectonics, Iberian Massif.

\section{INTRODUCTION}

A paleogeographic continental reconstruction for the late Paleozoic (Fig. 1) shows that three important Paleozoic belts, the northern Appalachians, the British and Scandinavian Caledonides, and the North German-Polish Caledonides, meet relatively close to the NW corner of the Iberian Massif. These belts mark the collision of three continental masses, Laurentia, Baltica, and Avalonia, which closed the Iapetus and Tornquist Oceans (which had opened during the Late Proterozoic and early Paleozoic). Avalonia likely formed close to Gondwana, because of its fauna (Cocks and Fortey, 1988), and it could also be considered a part of the Pan-African assemblage. It is viewed as a microcontinent or terrane assemblage detached from Gondwana in the Late Cambrian-Early Ordovician. It drifted away, creating the Rheic Ocean, and its subsequent closure during the Devonian gave rise to the Variscan belt in central and western Europe and northern Africa and to the Alleghanian orogen in North America (Hatcher, 1989, 2002; Winchester et al., 2002; van Staal et al., 1998).

Oceanic closure, which ultimately led to the formation of Pangea, occurred in several steps and gave rise to three groups of orogenic episodes, which are themselves diachronous. The first convergence-related events took place between the Late Cambrian and the Middle Ordovician. They have been described in the Scandinavian and British Caledonides (Finnmarkian and Grampian, respectively) and in the Appalachians (Taconic and Penobscottian), and they were related to arc-continent collisions in both sides of the Iapetus realm (Kelling et al., 1985; Hossack and Cooper, 1986; Stephens and Gee, 1989; van Staal, 2005; van Staal et al., 1998, this volume).

The second group of events took place between the Early Silurian and Late Devonian and was induced by the closure of Iapetus and the collision of Laurentia with Baltica (Scandian) in the north, and Laurentia with Avalonia in the south (Soper, 1988;
Rey et al., 1997). Details of the latter include the accretion of Ganderia - an arc formed at the Avalonian side of Iapetus- to Laurentia in the Early Silurian (Salinic), the collision of Avalonia in the Late Silurian-Early Devonian (Acadian), and subsequent dextral transpression during the late Early Devonian-Early Carboniferous (Neoacadian) (van Staal et al., 1998; Winchester et al., 2002; van Staal, 2005). Deformation and metamorphism occurred at the same time in exotic terranes that were later incorporated to the Variscan belt. They have been referred to as Ligerian (Cogné, 1977; Faure et al., 1997) and Eo-Variscan or early Variscan events, and they have been described in the Bohemian Massif (Franke, 2000; Franke and Zelazniewicz, 2002), the French Massif Central (Santallier et al., 1994), the Armorican Massif (Ballèvre et al., 1994), the Alps (von Raumer and Neubauer, 1993, 1994), and northwestern Iberia (Gómez Barreiro et al., 2006, 2007; Fernández-Suárez et al., this volume).

The third group of events spanned the Carboniferous and Early Permian, and it gave rise to intense deformation in Europe and Africa (Variscan) and the Appalachians (Alleghanian). These events resulted from the closure of the Rheic and Theic Oceans and collision of Gondwana with the previously formed Laurussia continent (Laurentia, Baltica, and Avalonia; Lefort, 1989).

The Variscan-Appalachian belt is linear but sinuous, with several oroclinal bends. In Europe (Fig. 2), the belt runs between two arcuate structures, the Bohemian Massif (Franke and Zelazniewicz, 2002) and the Iberian-Armorican arc (Bard et al., 1971; Ribeiro et al., 1995). An additional feature of the Variscan-Appalachian belt is the extent of transcurrent movements that have been active during most, if not all of the orogeny, and that have resulted in the terrane dispersion that hinders paleogeographic restoration (Gates et al., 1986; Hatcher, 1989, 2002; Martínez Catalán, 1990; Shelley and Bossière, 2000, 2002).

The northwestern corner of the Iberian Massif includes the Spanish regions of Galicia and the Cantabrian Mountains, as well 


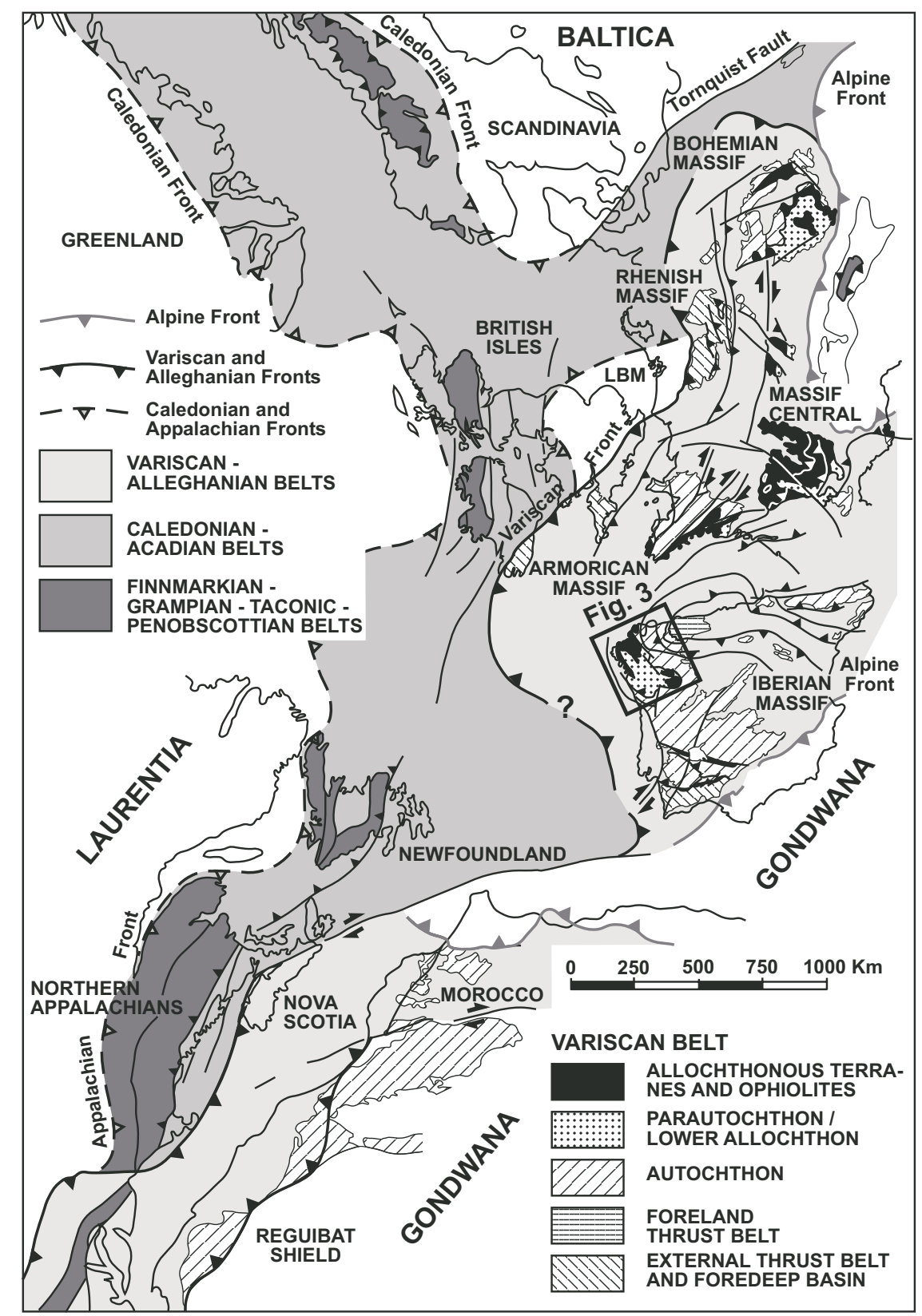

Figure 1. Sketch showing the position of Iberia in relation to the Appalachian, Caledonian, and Variscan belts at the end of Variscan convergence (modified from Martínez Catalán et al., 2002). LBM-London-Brabant Massif.

as northern Portugal, and it is located at the hinge zone of the Iberian-Armorican arc (Figs. 2 and 3). Coherent with its setting inside the Variscan mobile belt, the region preserves relics of one of the oceanic realms that once separated the early Paleozoic continents and recorded large amounts of orogenic shortening during their amalgamation. Strike-slip faults and shear zones exist but are not of continental scale, which implies that the Galiciannorthern Portugal section, including the Cantabrian Mountains, is retrodeformable and provides information about the orthogonal components of Gondwana-Laurussia plate convergence.
The northwestern Iberian basement consists of plutonic and metamorphic rocks with grades ranging from very low to catazonal, and a clear separation can be established between autochthonous and allochthonous terranes. The autochthon consists of a thick metasedimentary sequence deposited in northern Gondwana during the Late Proterozoic and Paleozoic, whereas the allochthon consists of the remnants of a huge and structurally complex nappe pile preserved in the core of late Variscan synforms. Both are separated by a thrust sheet, several kilometers thick, consisting of metasediments and volcanics derived 


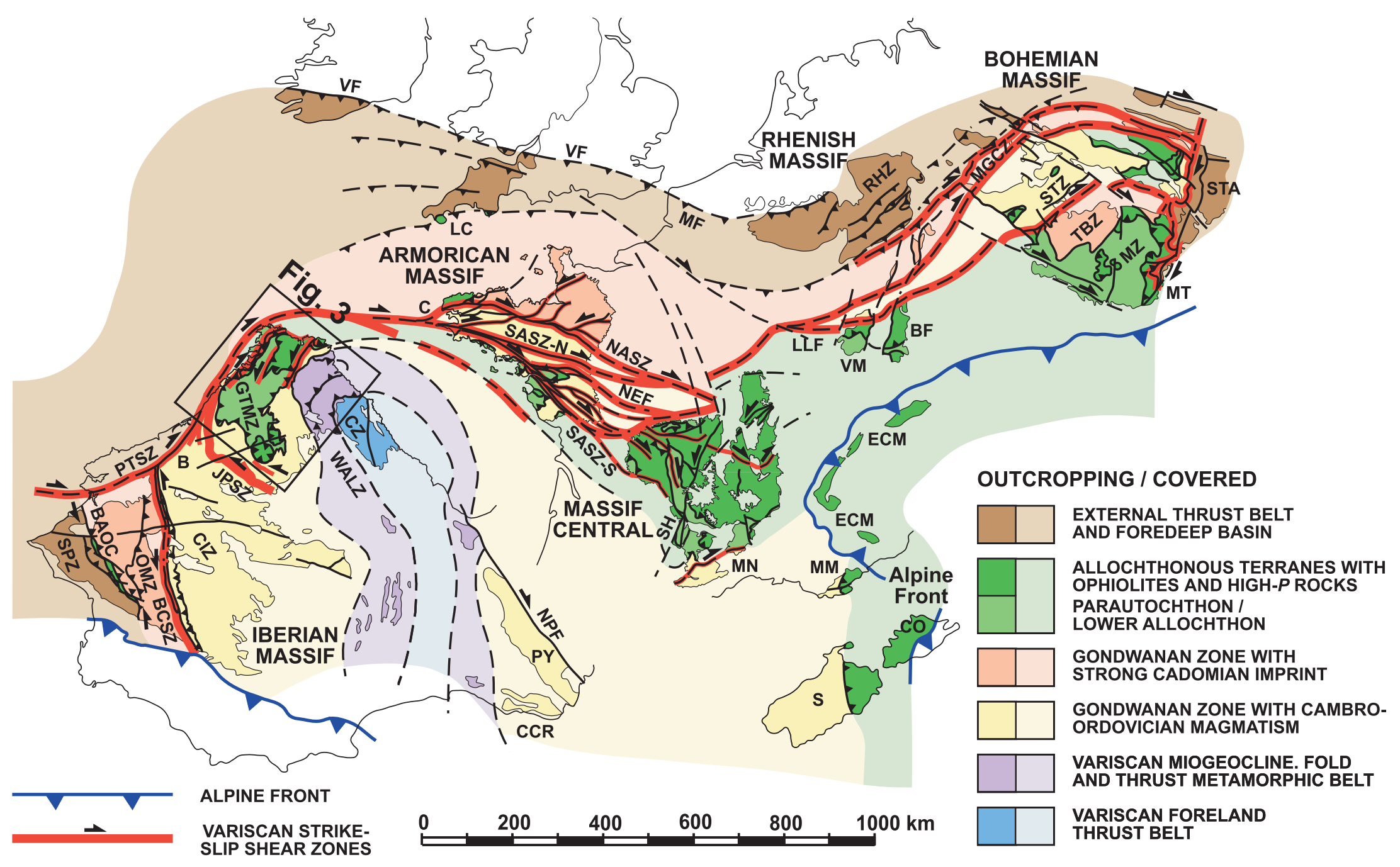

Figure 2. Subdivision of the Variscan belt showing the allochthonous terranes and the main transcurrent shear zones. Abbreviations: B-Buçaco; BAOC-Beja-Acebuches ophiolitic complex; BCSZ-Badajoz-Córdoba shear zone; BF-Black Forest; C-Crozon; CCR —Catalonia Coast Ranges; CIZ-Central Iberian zone; CO-Corsica; CZ-Cantabrian zone; ECM-External crystalline massifs of the Alps; GTMZ-Galicia-Trás-os-Montes zone; JPSZ—Juzbado-Penalva shear zone; LC-Lizard Complex; LLF-LayaleLubine fault; MF—Midi fault; MGCZ—Mid-German crystalline zone; MM-Maures Massif; MN—Montagne Noire; MT—Moldanubian thrust; MZ—Moldanubian zone; NASZ_North Armorican shear zone; NEF_-Nort-sur-Erdre fault; NPF_-North Pyrenean fault; OMZ_Ossa-Morena zone; PTSZ_Porto-Tomar shear zone; PY_Pyrenees; RHZ_-Rhenian-Hercynian zone; S—Sardinia; SASZ—South Armorican shear zone (N and S—northern and southern branches); SH—Sillon Houillier; SPZ_-South Portuguese zone; STA—Silesian terrane assemblage; STZ—Saxo-Thuringian zone; TBZ-Teplá-Barrandian zone; VF-Variscan front; VM-Vosges Massif; WALZ-West Asturian-Leonese zone. 


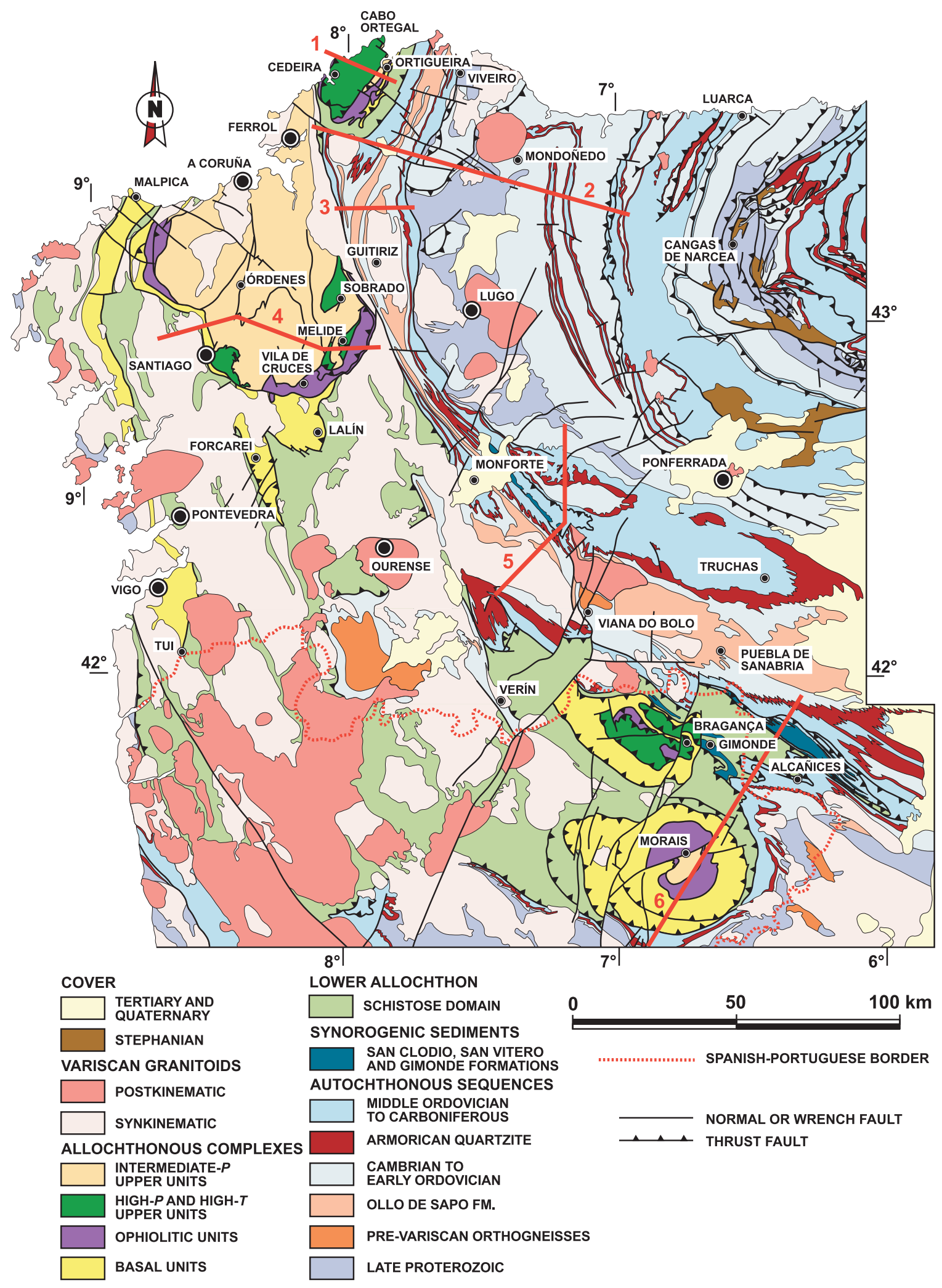

Figure 3. Geological sketch map of northwestern Iberia, showing the allochthonous complexes and their units. For location, see Figures 1 and 2. The locations of cross sections in Figure 4 are indicated. 
from the outer margin of Gondwana (Farias et al., 1987), often described as a parautochthon (Ribeiro et al., 1990). However, because stratigraphic continuity with the autochthon is broken (Valverde-Vaquero et al., 2005), it will be referred to here as the lower allochthon. The allochthonous terranes, together with the lower allochthon, are included in the so-called Galicia-Trás-osMontes zone (Farias et al., 1987).

\section{TECTONIC SETTING OF ALLOCHTHONOUS TERRANES}

There are three allochthonous complexes in Galicia (Cabo Ortegal, Órdenes, and Malpica-Tui), and two in northern Portugal (Bragança and Morais). They consist of a pile of allochthonous units characterized by unique lithologic associations and tectonometamorphic evolution. These units are separated from each other by faults, either thrusts or extensional detachments (Figs. 3 and 4). Three groups of allochthonous units can be recognized from bottom to top in ascending structural order: basal, ophiolitic, and upper units.

The basal units form a rather continuous thrust sheet consisting of schists and paragneisses alternating with felsic and mafic igneous rocks, of which granitic and peralkaline orthogneisses have yielded $\mathrm{Rb}-\mathrm{Sr}$ and $\mathrm{U}-\mathrm{Pb}$ ages of 490-470 Ma (Van Calsteren et al., 1979; García Garzón et al., 1981; Santos Zalduegui et al., 1995). The bimodal, partially alkaline magmatism reflects Ordovician rifting (Ribeiro and Floor, 1987; Pin et al., 1992). Since the basal units are not separated from the lower allochthon by ophiolites, it is assumed that they were part of Gondwana. Because the ophiolitic units overlie them, they are viewed as fragments of the most external edge of the Gondwanan continental margin. The Early Ordovician magmatism, partly peralkaline, probably resulted from the drift of a broken-away peri-Gondwanan terrane.

The ophiolitic units crop out discontinuously surrounding the upper units (Fig. 3) and form part of a formerly continuous and strongly imbricated nappe stack with at least two different types of ophiolite (see Arenas et al., this volume; Sánchez Martínez et al., this volume). Ophiolitic units occupying a relatively higher structural position represent the basal section of an ophiolite sequence that contains serpentinized harzburgitic ultramafic rocks, pegmatitic gabbros, and diabase dikes. Their geochemistry indicates a suprasubduction character, whereas zircons from leucogabbros yield a concordant U-Pb age of $395 \mathrm{Ma}$ (Díaz García et al., 1999; Pin et al., 2002), providing evidence for oceanic crust generation, and consumption, in Early Devonian time. The structurally lower ophiolitic units consist of greenschist-facies volcanic and plutonic mafic rocks (greenstones) and metapelites, with rare felsic orthogneisses, serpentinites, and cherts-all strongly deformed.

The upper units occupy the core of the allochthonous complexes (Fig. 4) and have been subdivided according to their metamorphic evolution into high-pressure $(P)$ and high-temperature $(T)$ upper units, below, and intermediate- $P$ upper units, above.
Both groups consist of terrigenous metasediments, orthogneisses, and metabasites, with the additional presence of ultramafic rocks in the high- $P$ and high- $T$ upper units. The metabasites include metagabbros, eclogites, high- $P$ and high- $T$ mafic granulites, and amphibolites. The gabbros and orthogneisses have yielded $\mathrm{U}-\mathrm{Pb}$ ages around $500 \mathrm{Ma}$, whereas detrital zircons in the metasediments indicate a maximum depositional age of $480 \mathrm{Ma}$ for the uppermost, greenschist-facies metagraywackes (FernándezSuárez et al., 2003), and 507 Ma for the structurally lower, high$P$ and high- $T$ paragneisses (Schäfer et al., 1993).

Most of the mafic rocks are metagabbros with tholeiitic compositions. Their geochemical signature has been compared to mid-ocean-ridge basalt (MORB) (Gil Ibarguchi et al., 1990) and related to continental rifting in the case of the high- $P$ and high- $T$ upper units (Galán and Marcos, 1997), whereas the intermediate- $P$ upper units have arc-tholeiitic affinities (Andonaegui et al., 2002; Castiñeiras, 2003). The additional presence of intermediate plutonic rocks, such as diorites and tonalites, in the intermediate$P$ upper units, reinforces the interpretation that these rocks were generated in an arc setting. Furthermore, geochemical studies of the ultramafic rocks of Cabo Ortegal are consistent with this hypothesis (Santos et al., 2002).

In spite of the arc affinities shown by some of them, the upper units seem to represent a terrane that had drifted away from Gondwana. The oldest ages obtained from upper intercepts and inherited zircons from the upper units (between 2.7 and $1.8 \mathrm{Ga}$; Kuijper, 1980; Peucat et al., 1990; Dallmeyer and Tucker, 1993; Schäfer et al., 1993) and the basal units (1.8 Ga; Santos Zalduegui et al., 1995) are similar to those found in the orthogneisses of the autochthon (Lancelot et al., 1985; Gebauer, 1993), and they are also similar to those of the West African craton. These ages point to a common Gondwanan basement for the upper and basal units and for the Iberian autochthon. Moreover, detrital zircon ages have been determined for graywackes from low-grade metasediments of an intermediate- $P$ upper unit in the Órdenes Complex, which yielded three age populations of 2.5-2.4 Ga, 2.1-1.9 Ga, and 610-480 Ma (Fernández-Suárez et al., 2003), which also record the major events in the West African craton of northern Gondwana.

On the other hand, Late Cambrian to Early Ordovician magmatism is widespread, not only in the allochthonous units, but also in the autochthon, and is a little older in the upper units (ca. 500 Ma; Dallmeyer and Tucker, 1993; Abati et al., 1999) than in the basal units or the autochthon (490-470 Ma; Van Calsteren et al., 1979; García Garzón et al., 1981; Vialette et al., 1987; Santos Zalduegui et al., 1995; Gebauer, 1993; Valverde Vaquero and Dunning, 2000). Magmatism has calc-alkaline and arc affinities in the autochthon (Ortega et al., 1996), in some of the allochthonous upper units, and in many granitoids of the allochthonous basal units, but some granites and mafic rocks of the latter are alkaline to peralkaline (Floor, 1966; Pin et al., 1992).

To reconcile the tectonic stability registered by the Early Ordovician passive-margin sediments of the autochthon (PérezEstaún et al., 1991), the rift-related magmatism of the basal units, 
Section 1

CABO ORTEGAL COMPLEX

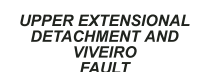

Section 2

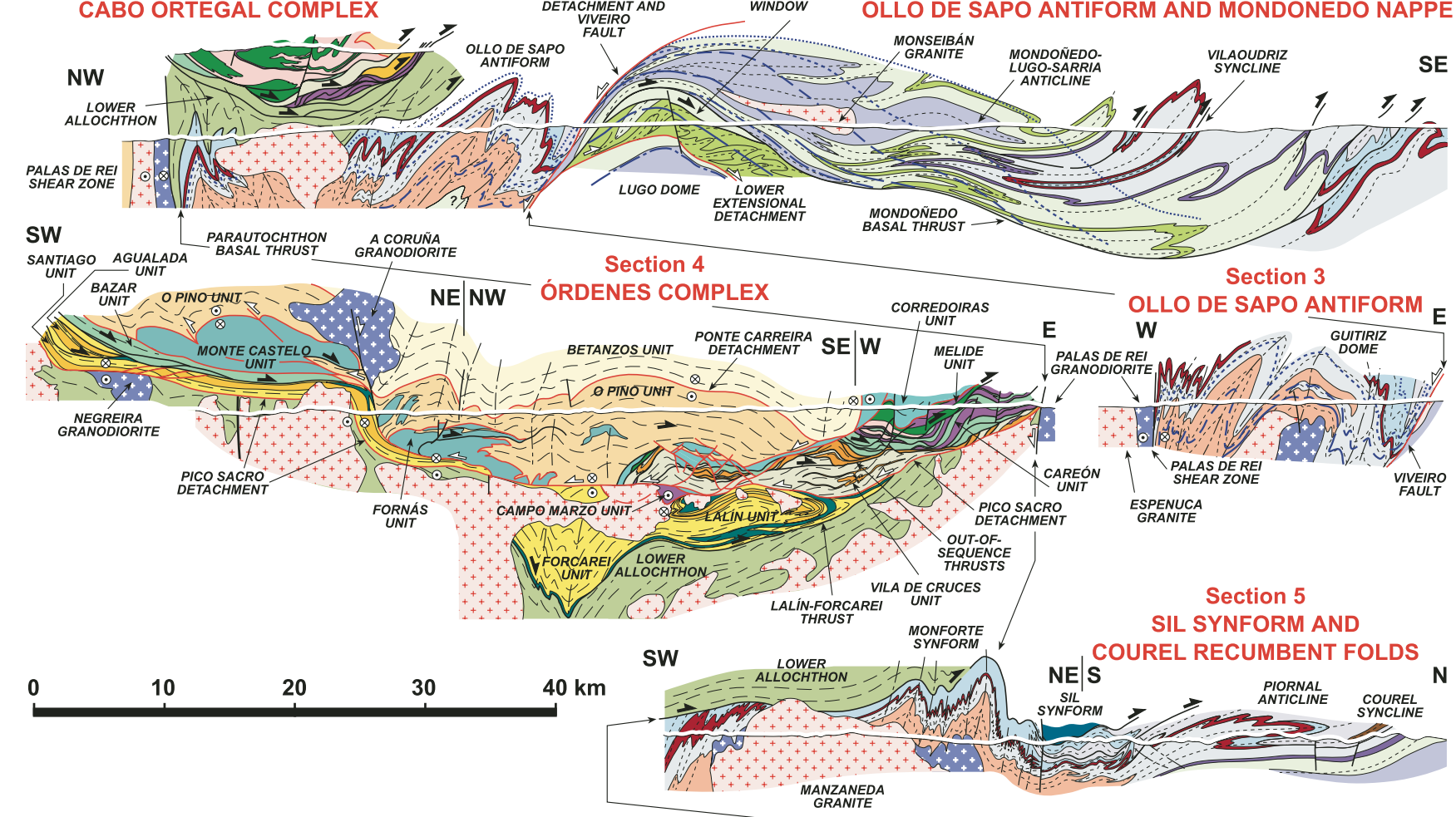

Section 6

sw
- LOWER ALLOCHTHON
BASAL THRUST

$$
\text { VILLADEPERA }
$$

ALCANIICES SYNFORM

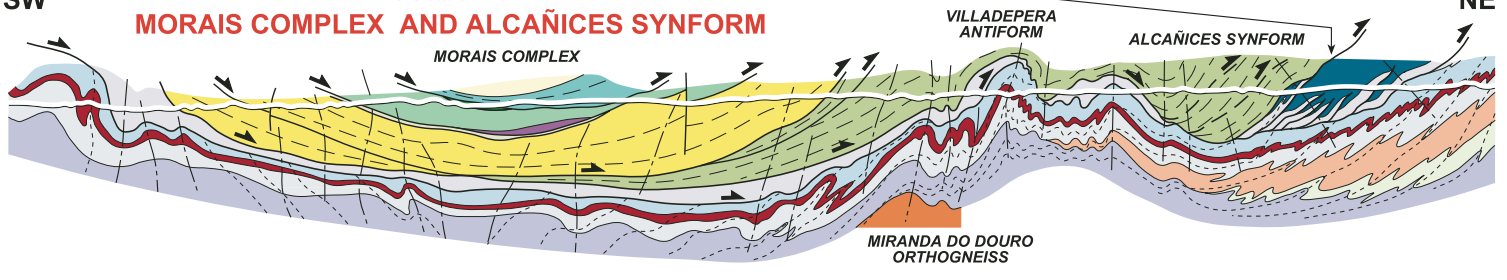

\section{MAIN FOLIATIONS AND CLEAVAGES}

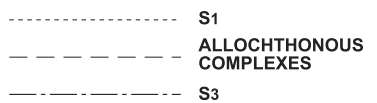

METAMORPHIC ISOGRADS

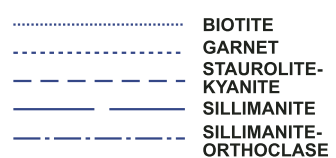

$\because * *$ LATE-KINEMATIC

TWO-MICA SYNKINEMATIC
++++++

**** SYNKINEMATIC

ALLOCHTHONOUS UNITS

INTERMEDIATE-P UPPER UNITS

LOW-GRADE SLATES

MEDIUM-GRADE SCHIST

ORTHOGNEISSES

METAGABBROS AND

HIGH-P AND HIGH-T UPPER UNITS

PARAGNEISSES

ECLOGITES, GRANULITES

ULTRAMAFIC ROCKS

PHIOLITIC UNITS

FLASERGABBROS AND
AMPHIBOLITES

ULTRAMAFIC ROCKS

LOW-GRADE
METAPELITES

LOW-GRADE

BASAL UNITS

PCHISTS AND

ORTHOGNEISSES

AMPHIBOLITES

OWER ALLOCHTHON

SCHISTS, META-SANDSTONES
AND VOLCANICS

AUTOCHTHON

SYNOROGENIC DEPOSITS:
GREYWACKES AND SLATES

DEVONAN: SLATES
AND LIMESTONES

SILURIAN: CARBONACEOUS

MIDDLE AND LATE ORDOVICIAN:
GREY SLATES AND QUARTZITES

EARLY ORDOVICIAN:
ARMORICAN QUARTZITE

MIDDLE CAMBRIAN-EARLY ORDO-
VICIAN: SLATES AND QUARTZITES

EARLY ORDOVICIAN:
OLLO DE SAPO PORPHYROID

OLLO DE SAPO PORPHYROI
EARLY ORDOVICIAN:

EARLY CAMBRIAN:
VEGADEO LIMESTONE

EARLY CAMBRIAN:
UPPER CANDANA QUARTZITE

EARLY CAMBRIAN:
SCHISTS AND QUARTZITES

LATE PROTEROZOIC: VILALBA SERIES
AND SCHIST-GREYWACKE COMPLEX

Figure 4. Geological sections across central and eastern Galicia and northern Portugal showing the main Variscan structures. Isograds of Variscan regional metamorphism have been drawn in sections 1, 2, and 3 to show their relationships to folding. See Figure 3 for locations. Sections are based on the following contributions: 1-Marcos et al. (1984) and Arenas (1988); 2-Bastida et al. (1982) and Martínez Catalán et al. (2003); 3—González Lodeiro et al. (1981); 4—Martínez Catalán et al. (2002); 5—Martínez Catalán et al. (2004); 6—Ribeiro (1974) and González Clavijo and Martínez Catalán (2002). 
the widely accepted early Paleozoic terrane dispersion in the peri-Gondwanan realm, and the calc-alkaline and arc affinities in the upper units and the autochthon, Valverde Vaquero and Dunning (2000) suggested that the rifting was located in a back-arc setting behind a subduction zone. This hypothesis is supported in reconstructions of peri-Gondwanan terranes by Stampfli et al. (2002), Winchester et al. (2002), von Raumer et al. (2003), and van Staal et al. (1998). Rollback of the subducting slab may have pulled Avalonia apart from Gondwana, and also the terrane partially preserved in the Galician upper allochthonous units. This terrane was possibly part of a discontinuous continental ribbon in the eastern continuation of Avalonia (Gómez Barreiro et al., 2007), and it recorded active-margin arc-related magmatism during separation (Fig. 5).

\section{OROGENIC EVOLUTION: THE CROSS-SECTION VIEW}

\section{Early Variscan Accretionary History}

In the upper allochthonous units, there is an increase in metamorphic grade from top to bottom, showing a transition from the uppermost epizonal units to mesozonal and catazonal units below. U-Pb dating of metamorphism has yielded two main age populations (Schäfer et al., 1993; Santos Zalduegui et al., 1996; Abati et al., 1999; Ordóñez Casado et al., 2001; Fernández-Suárez et al., 2002a, this volume). The older, dated around 500-490 Ma on monazite, whole zircon grains, and magmatic domains in zircon, is coeval with widespread magmatism and probably reflects high- $T$ and low- to intermediate- $P$ metamorphism in the magmatic arc. The younger age population, dated between 410 and $390 \mathrm{Ma}$ in monazite, zircon, and metamorphic overgrowths of zircon, is linked to initial Variscan convergence and high- $P$ and high- $T$ metamorphism. In fact, start of Variscan convergence should be older, because $410 \mathrm{Ma}$ would be the age of decompression melting associated with the onset of exhumation (Fernández-Suárez et al., this volume). Actually, ${ }^{40} \mathrm{Ar} /{ }^{39} \mathrm{Ar}$ data, which give a ca. $425 \mathrm{Ma}$ age for retrogressive amphibolitefacies foliation in high- $P$ and high- $T$ units, suggest an even older age for the high- $P$ and high- $T$ metamorphism (Dallmeyer et al., 1997; Gómez Barreiro, 2004; Gómez Barreiro et al., 2006).

This compressional event of Silurian to Early Devonian age produced a thick metamorphic pile, and the deep parts register pressures of 1.8 GPa or higher (Gil Ibarguchi et al., 1990; Mendia Aranguren, 2000). Thickening of the upper units and the subduction of some of them probably reflect their underthrusting following accretion to a large continental mass, either Baltica or Laurentia (Fig. 5). Accretion was followed by retrograde amphibolite-facies metamorphism in the lower parts of the accretionary wedge at 390-375 Ma (Dallmeyer et al., 1991, 1997; Valverde Vaquero and Fernández, 1996) related to the beginning of exhumation. The fact that units with differences of more than $1.2 \mathrm{GPa}$ in peak pressure occur presently in a sheet less than $10 \mathrm{~km}$ thick indicates that the original pile has been largely attenuated. Actu- ally, the different upper units are separated from each other by extensional faults (Figs. 4 and 5), interpreted as detachments developed in different stages of their stacking and emplacement (Martínez Catalán et al., 2002).

The ophiolitic units were stacked in several slices (Díaz García et al., 1999) and reached metamorphic conditions ranging between $625^{\circ} \mathrm{C}$ and $680{ }^{\circ} \mathrm{C}$ and 1.1 and $1.2 \mathrm{GPa}$. Amphibolitefacies prograde metamorphism, dated at 390-380 Ma (Dallmeyer and Gil Ibarguchi, 1990; Dallmeyer et al., 1991, 1997), was coeval with retrograde metamorphism in the upper units, thus suggesting that underthrusting and imbrication of oceanic lithosphere caused exhumation of the overlying upper units (Fig. 5).

The basal units record a high- $P$ regional metamorphic event not found in the lower allochthon or in the autochthon. Peak pressures reached 1.5-1.7 GPa in a west-directed subduction zone (in present coordinates), as deduced from the pressure gradient along both limbs of a huge recumbent anticline (Fig. 4, section 4; Arenas et al., 1995; Martínez Catalán et al., 1996). Subduction may have started ca. $380 \mathrm{Ma}$ and ended ca. $365 \mathrm{Ma}$ (Van Calsteren et al., 1979; Santos Zalduegui et al., 1995; Rodríguez et al., 2003).

\section{Variscan Collisional Deformation: Thrust and Nappe Tectonics}

The structural evolution of the autochthon and lower allochthon is relatively simple, and the structures are related to three main compressional events that developed during convergence following collision (Pérez-Estaún et al., 1991). The first event $\left(\mathrm{D}_{1}\right)$ produced recumbent folds with east vergence and axial planar cleavage $\left(\mathrm{S}_{1}\right)$, which is the oldest penetrative fabric recognized. Large $\mathrm{D}_{1}$ folds occur in the Mondoñedo nappe (Fig. 4, section 2): the Mondoñedo-Lugo-Sarria anticline and the Vilaoudriz syncline (Matte, 1968; Bastida et al., 1986). Their common overturned limb reaches $15-30 \mathrm{~km}$ due to late horizontal shearing related partly to thrusting and partly to late orogenic extension. To the west, recumbent folds are common in low-grade areas, but they are smaller, and their reverse limbs rarely attain $5 \mathrm{~km}$.

The youngest deposits preserved in the core of one of the recumbent synclines are Early Devonian (Fig. 4, section 5), and ${ }^{40} \mathrm{Ar} /{ }^{39} \mathrm{Ar}$ dating of regional $\mathrm{S}_{1}$ cleavage yielded ages of $359 \mathrm{Ma}$ close to the allochthonous complexes and $336 \mathrm{Ma}$ to the east, far away from them and adjacent to the Cantabrian zone (Dallmeyer et al., 1997). When compared with deformation ages in the allochthonous units, $\mathrm{S}_{1}$ in the autochthon developed immediately after the greenschist-facies foliation in the structurally lower ophiolites (363-367 Ma; Dallmeyer et al., 1997) and the end of subduction-related metamorphism in the basal units (365 Ma; Rodríguez et al., 2003). It seems that once continental subduction of the outermost edge of Gondwana became locked, shortening began in inner parts of its continental platform, giving rise first to recumbent folds $\left(D_{1}\right)$, and then to large thrust sheets, described as the second deformational event $\left(\mathrm{D}_{2}\right)$.

Four large thrusts developed in the internal zones of northwestern Iberia (Figs. 4 and 5). The Lalín-Forcarei thrust carried 


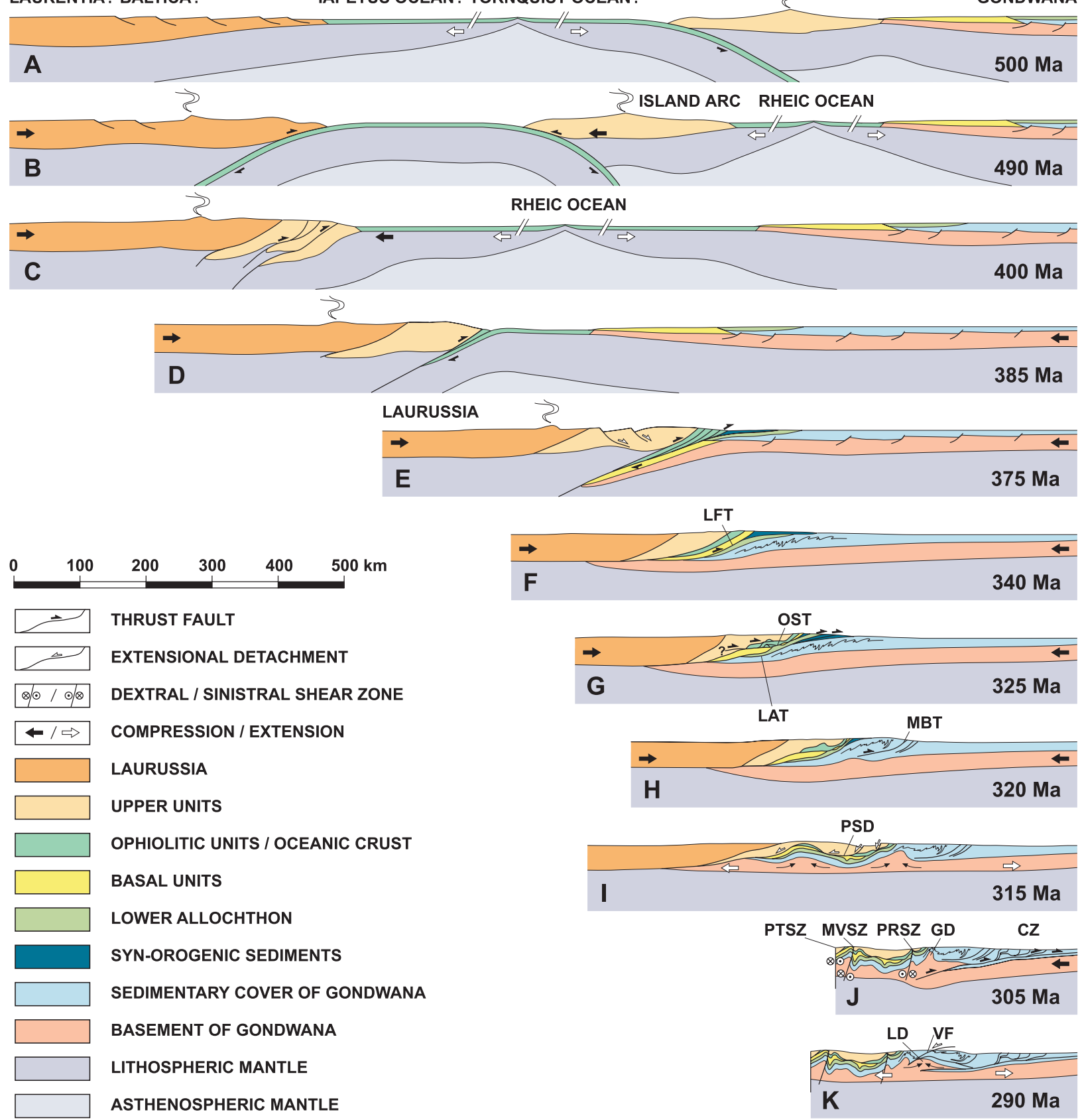

Figure 5. Proposed stages in the tectonic evolution of northwest Iberia. A: Individualization of a peri-Gondwanan terrane by slab rollback, and arc-related magmatic activity during the Late Cambrian to Early Ordovician. B: Drifting of the peri-Gondwanan terrane away from Gondwana and spreading of the Rheic Ocean. C: Building of an accretionary wedge by underthrusting and imbrication of the peri-Gondwanan terrane during the Silurian to Early Devonian. D: Closure of the Rheic Ocean and imbrication of oceanic slices. E: Subduction of outer edge of the Gondwanan continental margin in the Middle to Late Devonian. F: Thrusting of allochthonous units over the lower allochthon during the Early Carboniferous. G: Development of out-of-sequence thrusts in the Early to Middle Carboniferous. H: Thrusting in more external parts of the belt during the Middle Carboniferous. I: Collapse and extension of Gondwanan thickened crust with formation of extensional detachments and domes. J: Late upright folding, strike-slip faulting, and thin-skinned tectonics in the foreland during the Late Carboniferous. K: Extensional collapse migrates to the east, probably in response to crustal thickening induced by underthrusting of basement to the west during thin-skinned shortening in the foreland. Note that W-E coordinates correspond to present. Past coordinates might have varied from NE-SW to NW-SE during the time interval covered by the cartoon, according to the paleoposition of continental masses in the reconstruction by Winchester et al. (2002). Abbreviations: CZ_Cantabrian zone; GD—Guitiriz dome; LAT_lower allochthon thrust; LD—Lugo dome; LFT_Lalín-Forcarei thrust; MBT_Mondoñedo basal thrust; MVSZ_-Malpica-Vigo shear zone; OST_out-of-sequence thrusts; PRSZ_Palas de Rei shear zone; PSD_Pico Sacro detachment; PTSZ_Porto-Tomar shear zone; VF-Viveiro fault. 
the basal units over the lower allochthon after $346 \mathrm{Ma}$, which is the age of migmatization in allochthonous paragneisses (U$\mathrm{Pb}$ in monazite and rutile; Abati and Dunning, 2002). The $\mathrm{S}_{2}$ cleavage in the underlying lower allochthon, which developed during emplacement of the Lalín-Forcarei thrust, was dated at $340 \mathrm{Ma}\left({ }^{40} \mathrm{Ar} /{ }^{39} \mathrm{Ar}\right.$; Dallmeyer et al., 1997). The upper and ophiolitic allochthonous units subsequently moved over the basal units and the lower allochthon, becoming strongly imbricated along the sole thrust. As they had been previously stacked and internally imbricated in sequence, the new thrust system developed out of sequence (Martínez Catalán et al., 2002). The age of the out-of-sequence thrusts is constrained between $340 \mathrm{Ma}$, age of the Lalín-Forcarei thrust, and $323 \pm 11 \mathrm{Ma}$, age of the Palas de Rei granodiorite (Bellido et al., 1992), or $317 \pm 15 \mathrm{Ma}$, age of the Espenuca granite (Ortega Cuesta, 1998), both of which postdate nappe emplacement and predate the Pico Sacro extensional detachment. A $325 \mathrm{Ma}{ }^{40} \mathrm{Ar} /{ }^{39} \mathrm{Ar}$ age obtained by Dallmeyer et al. (1997) in an ultramylonite from a high- $P$ and high- $T$ upper unit may be a representative age for the out-ofsequence thrusts.

The isotopic data are consistent with the age and structural relationships of synorogenic flysch deposits that crop out close to the eastern boundary of the Bragança Complex in Portugal, in the Alcañices synform in Zamora, and in a narrow synform in central Galicia (Fig. 3; Fig. 4, sections 5 and 6). They consist of low-grade slates, graywackes, and conglomerates with plant debris and metamorphic pebbles (Riemer, 1966; Matte, 1968; Martínez García, 1972; Pérez-Estaún, 1974; Ribeiro and Ribeiro, 1974) cropping out in imbricates inside and in front of the lower allochthon thrust sheet (González Clavijo and Martínez Catalán, 2002; Martínez Catalán et al., 2004). The synorogenic deposits are turbiditic and have been dated as Late Devonian (Frasnian) in Portugal, using palynomorphs (Pereira et al., 1999), and as early Namurian using the age of the youngest detrital zircon in the Sil synform in central Galicia (Martínez Catalán et al., 2004). Here, zircon age populations are more compatible with those of the allochthonous terranes than with the autochthon because they lack the 1.1-1 Ga Mesoproterozoic population, which is well represented in the autochthonous succession (Fernández-Suárez et al., 2000b, 2002b; Martínez Catalán et al., 2004). This suggests that the synorogenic turbidites were deposited in a trough that developed in front of the allochthonous terranes during their emplacement by thrusting (González Clavijo and Martínez Catalán, 2002; Martínez Catalán et al., 2004). Their age is older near the Bragança Complex than in central Galicia, which reflects the advance of the allochthonous sheet.

The emplacement of the lower allochthon, carrying the allochthonous terranes piggyback, took place along a nearly horizontal detachment, the lower allochthon thrust. It has an apparent displacement of nearly $200 \mathrm{~km}$ and is a wonderful example of thin-skinned tectonics in the hinterland of a collisional belt (Fig. 4, sections 5 and 6). Silurian carbonaceous slates were the weak layer that accommodated the detachment, and they became strongly phyllonitized (Farias et al., 1987; Farias Arquer, 1990; González Clavijo and Martínez Catalán, 2002; Marcos and Llana Fúnez, 2002). The low amplitude of the previous $\left(D_{1}\right)$ recumbent folds left the stratigraphic sequence nearly undisturbed, allowing the thrust surface to utilize the graphite-rich Silurian slates. Fan-like imbricates at the lower allochthon thrust front are well preserved in the Alcañices synform (González Clavijo and Martínez Catalán, 2002). In the Sil synform, the younger detrital zircon (dated $324 \pm 7 \mathrm{Ma}$ ) constrains the age of the lower allochthon thrust as late Viseanearly Namurian (Martínez Catalán et al., 2004). Its motion was nearly synchronous with the later out-of-sequence thrusts, or somewhat younger.

The fourth large fault, the Mondoñedo basal thrust, developed further east, carrying the large recumbent folds previously formed and possibly enlarging their amplitude by ductile flow concentrated at its basal shear zone (Bastida et al., 1986; Aller and Bastida, 1993; Martínez Catalán et al., 2003). The precise age of the Mondoñedo basal thrust is unknown, but two thrust faults east of the Mondoñedo basal thrust were dated by Dallmeyer et al. (1997) at ca. 320 Ma.

Several other minor thrust faults developed to the east of the Mondoñedo basal thrust, and thrusting became very important in the Cantabrian zone (Figs. 2 and 5), a thin-skinned foreland thrust belt where these structures are the main ones responsible for orogenic shortening (Pérez-Estaún et al., 1988).

\section{Variscan Orogenic Collapse and Late Variscan Folding}

Closely following the emplacement of the allochthonous terranes and thrust imbrication of the autochthon, relatively deep parts of the crust underwent a temperature increase associated in part with decompression. A pervasive subhorizontal tectonic foliation developed in the middle and lower parts of the autochthonous section, from the biotite zone down to the deepest accessible parts of the crust, cropping out in the core of late-orogenic extensional domes. The foliation is a crenulation cleavage in the upper parts, but it passes quickly to a schistosity and a gneissose banding downward, in the sillimanite-Kfeldspar zone.

Extension is demonstrated by the thinning and even disappearance of some of the previously metamorphic zones at several map-scale shear zones, equivalent to ductile detachments, and by the metamorphic evolution on both sides of them: isobaric heating at their hanging wall and isothermal decompression at their footwall (Escuder Viruete et al., 1994; Díez Balda et al., 1995; Arenas and Martínez Catalán, 2003; Martínez Catalán et al., 2004). Kinematic criteria demonstrate a noncoaxial component of deformation with a sense of shear that varies from one detachment to other and indicate extension normal, oblique, and parallel to the orogenic trend.

Extension occurred under the allochthonous terranes, and also to the east, in the Ollo de Sapo antiform and in the Mondoñedo nappe. For instance, the Pico Sacro detachment developed 
between the Órdenes Complex and the migmatite and granite assemblage below (Fig. 4, section 4; Fig. 5). The Guitiriz dome is also an extensional structure, which, as many others, evolved into a dome (Fig. 4, section 3; Fig. 5).

The Lugo dome (Fig. 4, section 2) developed in the internal parts of the Mondoñedo nappe, which has footwall units that crop out in two tectonic windows related to doming. There, internal extension and two extensional ductile detachments stretched the nappe and its relative autochthon and are responsible for most of the stretching undergone by the reverse limb of the two largest recumbent folds (Fig. 5). One of the extensional detachments affected the footwall unit, whereas the other strongly attenuated the thrust sheet and evolved into a brittle structure, the Viveiro fault, which cuts across the whole Mondoñedo nappe and its footwall unit (Arenas and Martínez Catalán, 2003; Martínez Catalán et al., 2003). The difference in peak pressure between both sides of the upper extensional detachment and the Viveiro fault has been estimated to be 0.4-0.5 GPa (Reche et al., 1998), roughly equivalent to a subtraction of $15-19 \mathrm{~km}$ by the shear zone and the fault.

One of the main characteristics of the geological map of northwestern Iberia is the alternation of domes and basins (Martínez et al., 1988), which in many cases implies crustal-scale boudinage enhanced by deep crustal flow. Heat accumulation due to crustal thickening and some advection of mantle-derived rocks (Galán et al., 1996) caused partial melting, lowering the viscosity of the middle and lower crust, and facilitated viscous flow that accommodated extension of the whole crust, probably in response to gravitational forces. High-grade autochthonous rocks - the youngest parageneses of which are high- $T$ and low- $P$-crop out in the domes, accompanied by abundant Variscan granitoids, whereas the basins are occupied by lowgrade autochthonous metasediments and, in five cases, by the remnants of the allochthonous terranes preserved as klippen (Fig. 3).

Late upright folds are related to the third compressional event $\left(D_{3}\right)$ and are associated with a crenulation cleavage $\left(S_{3}\right) \cdot D_{3}$ macrostructures interfere with $\mathrm{D}_{1}$ recumbent folds and are easy to identify because they fold the regional metamorphic isograds. Large $\mathrm{D}_{3}$ folds commonly nucleated in previously developed domes and basins, and they vary from open to tight. Variations in flattening are due to heterogeneous strain associated with subvertical, transcurrent ductile shear zones (Iglesias Ponce de León and Choukroune, 1980).

The main phase of gravitational collapse and extension occurred between 320 and $310 \mathrm{Ma}$, which are the ages of many synkinematic granitoids (Fernández-Suárez et al., 2000a). This part of collapse is considered intra-orogenic for two reasons. One is that the extensional domes and basins were overprinted by upright folds and transcurrent ductile shear zones, as in the case of the Guitiriz dome (Fig. 4, section 3; Fig. 5). The other is that extension in the internal zone was followed by shortening in the Cantabrian zone (Figs. 2 and 5), a thin-skinned foreland thrust belt that developed to the east between 312 and 300 Ma (Pérez-Estaún et al., 1988).
Upright $\mathrm{D}_{3}$ folds have been dated by synkinematic granitoids at $314 \pm 6 \mathrm{Ma}$ (Capdevila and Vialette, 1970; Ries, 1979), whereas strike-slip shear zones closely related to their development moved between 315 and 305 Ma (Regêncio Macedo, 1988; Valle Aguado et al., 2005).

However, the Lugo dome developed later, as demonstrated by ${ }^{40} \mathrm{Ar}{ }^{39} \mathrm{Ar}$ cooling ages around $300 \mathrm{Ma}$ (Dallmeyer et al., 1997), and also because the continuation to the south of the Viveiro fault, which bounds its western flank, cuts and deforms a late-kinematic granodiorite massif with a $\mathrm{Rb}-\mathrm{Sr}$ age of 286 \pm 6 Ma (Román-Berdiel et al., 1995; Ortega et al., 2000), which belongs to the same series as others dated by U-Pb at ca. $295 \mathrm{Ma}$ (Fernández-Suárez et al., 2000a). Late development of the Lugo dome was probably a consequence of migration of the extension to the external zones of the orogen with time (Fig. 5), in the same way that compressional episodes $\mathrm{D}_{1}$ and $\mathrm{D}_{2}$ had done before, as shown by the diachronous character of their associated cleavages (Dallmeyer et al., 1997).

The amount of extension undergone by the orogenic crust is difficult to estimate, but it seems to be very important given the abundance of extensional detachments and the high strains associated with them and the accompanying regional fabrics. Consequently, the apparently huge displacement shown by the main Variscan thrusts in the allochthonous terranes, including $\sim 200 \mathrm{~km}$ for the lower allochthon thrust, may to a large extent be a consequence of late orogenic extension and would have been originally much less (Fig. 5).

\section{GLOBAL VIEW: THE THIRD AND FOURTH DIMENSIONS}

\section{The Pieces of the Puzzle}

Iberian geology can be correlated with that of central Europe by comparing its stratigraphic, metamorphic, and magmatic features with those of the different zones of the European massifs. The zoning of the Variscan belt was first established in central Europe by Kossmat (1927), and in Iberia by Lotze (1945), and correlations are being continuously updated as more information becomes available (Bard et al., 1971; Julivert et al., 1972; Tollman, 1982; Franke, 1989; Martínez Catalán, 1990; Matte, 2002).

In Figure 2, a correlation has been attempted using a few simple criteria. The autochthonous Central Iberian zone can be compared with the central domain of the Armorican Massif in France based on continuity across the Iberian-Armorican arc and strong stratigraphic similarities (Robardet et al., 1990; Young, 1990). The Ossa-Morena zone of southern Iberia is usually correlated with the northern domain of the Armorican Massif based on the presence of a strong Cadomian imprint and also on stratigraphic grounds (Cogné, 1974; Eguíluz et al., 1984, 2000; Chantraine et al., 1994). It is important to note that the sedimentary and faunal records in Iberia indicate that these zones were part of the northern Gondwanan shelf, distal in the case of the Ossa-Morena zone and proximal in the case of the Central Iberian zone (Robardet and Gutiérrez-Marco, 2004). 
The correlation can be continued to the Bohemian Massif based on the presence of Cadomian crust in the Mid-German crystalline zone and the Saxo-Thuringian zone, and also based on the presence of a Cambrian-Ordovician rift sequence in the latter, which shows a stronger similarity to the Central Iberian zone than to the Ossa-Morena zone (Franke, 1989, 2000; Linnemann and Romer, 2002; Linnemann et al., 2003; Robardet and Gutiérrez-Marco, 2004). The Teplá-Barrandian zone has also evident affinities with the autochthonous terranes of northern Gondwana (Franke, 2000), and it includes some of the best-preserved Cadomian basement in Europe. This fact and the Paleozoic succession and faunal similarities (Gutiérrez-Marco et al., 1999, 2001) suggest a connection with the Iberian Ossa-Morena zone or with a zone transitional between the Ossa-Morena zone and the Central Iberian zone.

Exotic terranes with Paleozoic ophiolites, remnants of Cambrian-Ordovician volcanic arcs, and early Variscan high- $P$ metamorphism similar in age and evolution to the northwestern Iberian terranes exist along the whole length of the Variscan belt (Fig. 2). They occur in the southern domain of the Armorican Massif (Hanmer, 1977; Marchand, 1981; Balé and Brun, 1986; Ballèvre et al., 1994), in the French Massif Central (Burg and Matte, 1978; Girardeau et al., 1994; Ledru et al., 1994a, 1994b), the Vosges and Black Forest massifs (Wimmenauer and Lim, 1988; Eisbacher et al., 1989; Franke, 1989, 2000), the SaxoThuringian and Moldanubian zones of the Bohemian Massif (Tollman, 1982; Behr et al., 1982, 1984; Franke, 1989, 2000; Crowley et al., 2002), and the Polish Sudetes (O'Brien et al., 1997; Kröner and Hegner, 1998; Timmermann et al., 2000; Aleksandrowski and Mazur, 2002; Floyd et al., 2002). Furthermore, the exotic terranes seem to continue to the south in the External crystalline massifs of the Alps and the Maures Massif in southern France, Corsica, and northern Sardinia (Bourrouilh et al., 1980; Frisch et al., 1984, 1987; Becker et al., 1987; Ménot et al., 1988; Vauchez and Bufalo, 1988; von Raumer and Neubauer, 1993, 1994; von Raumer et al., 2002).

Finally, the Rhenian-Hercynian zone wraps around the other zones and can be traced from the Bohemian Massif to the southern British Isles and to southern Iberia, where it is represented by the South Portuguese zone (Oliveira et al., 1979). The Rhenian-Hercynian zone is an external thrust belt and also a foredeep basin that developed during the Middle Devonian and Carboniferous, possibly on Avalonian crust adjacent to the developing Variscan mountain belt.

The correlation shown in Figure 2 by itself does not provide a straightforward interpretation of the history of terrane evolution, convergence, and collision. One of the most important problems to be solved is the paleoposition and origin of the allochthonous terranes. Considering the paleogeographic continental reconstruction for the late Paleozoic (Fig. 1), the ophiolites of northwest Iberia and similar units in central Europe seem to witness an oceanic realm between Gondwana, represented by the autochthon, and Avalonia, represented by the London-Brabant Massif and the eastern Appalachians (Rast and Skehan, 1983; Williams and Hatcher, 1983).
According to current reconstructions (Scotese, 2001; Winchester et al., 2002), that ocean would have been the Rheic. However, it is unrealistic to postulate that the ca. $500 \mathrm{Ma}$ arc-type magmatism preserved in the upper allochthonous units occurred inside the Rheic Ocean when it was beginning to open. Actually, arc development at that time was widespread in the Iapetus Ocean, on the northern side of Avalonia (van Staal et al., 1998; Winchester et al., 2002; van Staal, 2005). Therefore, correlation of the upper allochthonous units with, for instance, an arc occurring outboard of the Iapetus margin of Avalonia is more reasonable.

These facts can be reconciled if the upper units are remnants of a peri-Gondwanan continental block that was drifting at the same time as Avalonia (Gómez Barreiro et al., 2007) or that was detached from its Iapetus margin. These units would have registered active-margin magmatism and, later, would have docked to Laurussia, facing the Rheic Ocean, with Gondwana at the opposite margin, and without any intervening Avalonian terrane (Fig. 5). This possibility would imply that Avalonia did not form a continuous ribbon between Gondwana and Laurussia, at least, not for its easternmost part. Moreover, it is possible that the unstable ocean that drove the slab rollback that detached the upper allochthonous units from Gondwana was not the Iapetus, but the Tornquist Ocean (Fig. 5).

A major problem in interpreting the Variscan belt is how many peri-Gondwanan terranes were involved and how many oceans developed among them. Some interpretations suggest that nearly every ophiolitic unit represents a suture, so that several microcontinents, arcs, and oceans were involved (Matte, 1986, 1991, 2002; Franke, 1989, 2000; Franke and Zelazniewicz, 2002). However, different ophiolites and associated allochthonous units occur in terranes separated from each other by strike-slip shear zones, which suggests that different possible sutures could in fact be the same, repeated by wrench tectonics. The correlation among the Variscan exotic terranes was explored by Martínez Catalán (1990), who concluded that all of them could be remnants of a single gigantic, tongue-shaped allochthonous sheet and that a single ocean might account for all terranes of oceanic affinity. Although possible on purely geometrical grounds, the tongue shape of the allochthon seems mechanically unreasonable and can be replaced by a rather continuous strip along the northern Gondwana platform if the transpressional character of the orogen is considered.

\section{Strike-Slip Tectonics}

One of the clues for any interpretation of the Variscan belt resides in the relationship between northwest Iberia and the Armorican Massif, on both sides of the Iberian-Armorican arc. There is a close stratigraphic similarity between the Central Iberian zone and the central Armorican Massif, which has Ordovician and Devonian sections that are identical in Buçaco (western Portugal) and Crozon (western Armorican Massif; Henry et al., 1974; Paris and Robardet, 1977; Robardet et al., 1990; Young, 1990; Paris, 1998), precluding the possibility that both 
were separated by an oceanic domain. However, the Central Iberian zone and the central domain of the Armorican Massif lie on different sides of the allochthonous terranes (Fig. 2), suggesting that they were separated by a suture, the Massif Central suture of Matte (1991).

This apparent contradiction may be solved from an Iberian perspective. In the southern Armorican Massif, the allochthonous terranes occur adjacent to the southern branch of the South Armorican shear zone, which is considered to overprint the root there (Ballèvre et al., 1994). However, in Iberia, the allochthonous terranes overlie the Central Iberian zone, and their root zone lies outside, to the north, west, or south of the Central Iberian zone. It seems reasonable that the Armorican terranes are also allochthonous and do not root in the southern domain of the massif, in spite of the fact that they seem to root there because they have been overprinted and masked by subvertical shear zones. Therefore, the suture would be rootless in both domains, and the present terrane distribution may be a consequence of wrench tectonics.

Shelley and Bossière $(2000,2002)$ developed the hypothesis that the terrane collage was essentially due to dextral transpression induced by sliding of Laurentia along the northern margin of Gondwana. Their interpretation relies largely on continental reconstructions by Dalziel et al. (1994) and Dalziel (1997), and in well-established evidence for pervasive Devonian-Carboniferous dextral shearing in the Variscan-Appalachian belt (Gates et al., 1986; Rolet et al., 1994; van Staal and De Roo, 1995; Franke and Zelazniewicz, 2002; Hatcher, 2002).

Shelley and Bossière were right in stressing the importance of strike-slip motion, but paid little attention to the orthogonal component of convergence. However, the importance of orthogonal components is suggested by the subduction and subsequent exhumation of high- $P$ allochthonous units and by the large displacement of allochthonous terranes in northwest Iberia and in the Bohemian Massif. Figure 6 is a simplified attempt to incorporate both orthogonal and transcurrent components into a model for the development of the Variscides in a way that is geometrically feasible. It avoids the need to invoke "extra" peri-Gondwanan terranes and intervening oceans.

Our foundations are the tectonic evolution of northwestern Iberia, the evidence that its section is retrodeformable, and the fact that the allochthonous terranes in the Galicia-Trás-os-Montes zone contain a rootless suture.

Both the Galicia-Trás-os-Montes zone and the Central Iberian zone are truncated to the west by the Porto-Tomar dextral shear zone (Ribeiro et al., 1980), which continues into the South Armorican shear zone (Fig. 2). The Galicia-Trás-os-Montes zone might root at a possible cryptic suture at the boundary between the Central Iberian zone and the Ossa-Morena zone, or farther south, between the latter and the South Portuguese zone, where a true suture exists.

The first possibility was explored by Simancas et al. (2002), and it is supported by the presence of a unit comparable to the basal units of the Galicia-Trás-os-Montes zone in the BadajozCórdoba sinistral shear zone, which represents the Central Iberian
zone-Ossa-Morena zone boundary. However, no ophiolites have been found here, and it is not clear whether these units actually root there or are a narrow klippe pinched at the Badajoz-Córdoba sinistral shear zone. Furthermore, the existence of an oceanic domain between the Central Iberian zone and the Ossa-Morena zone in the Paleozoic is not favored by faunal studies (Robardet, 2002, 2003; Robardet and Gutiérrez-Marco, 2004).

Conversely, ophiolites occur in the Beja-Acebuches ophiolitic complex, at the Ossa-Morena zone-South Portuguese zone boundary (Crespo-Blanc, 1991; Fonseca and Ribeiro, 1993; Quesada et al., 1994; Figueiras et al., 2002). The age of these ophiolites is unknown, but their position in the Variscan belt is similar to those of Lizard in south Cornwall (Fig. 2), dated at 390-400 Ma (U-Pb; Clark et al., 1998; Nutman et al., 2001), so that the Beja-Acebuches ophiolitic complex may be coeval with and perhaps linked to the upper ophiolites of the Galicia-Trás-osMontes zone, dated at 395 Ma (see also Sánchez Martínez et al., this volume).

Vergences are opposite in the Beja-Acebuches ophiolitic complex suture and the Galicia-Trás-os-Montes zone allochthonous terranes: while emplacement of the Galicia-Trás-os-Montes zone has an eastward component in present coordinates, the recumbent folds and thrusts in the South Portuguese zone, BejaAcebuches ophiolitic complex, and Ossa-Morena zone show a southwest-directed motion (Silva et al., 1990; Crespo Blanc, 1991; Onézime et al., 2002; Expósito et al., 2002, 2003; Simancas, 2004). This does not necessarily imply that both sutures represent two different oceans, as the opposite vergences may indicate a change in subduction polarity along the plate boundary of a single ocean.

Faunal evidence indicates that the Central Iberian zone and the Ossa-Morena zone were never separated from each other by an ocean during the Paleozoic (Robardet, 2002, 2003; Robardet and Gutiérrez-Marco, 2004), and we assume that both the BejaAcebuches ophiolitic complex and the Galicia-Trás-os-Montes zone sutures represent the closure of the Rheic Ocean by collision between Gondwana and Laurussia. However, the evolution of each suture was very different. To the east, closure of the Rheic Ocean built an accretionary wedge in the active Laurussia margin, which was later emplaced as a gigantic thrust over the northern Gondwana continental platform (Figs. 5 and 6).

To the west, south-directed subduction of oceanic lithosphere created the Rhenian-Hercynian zone (Kossmat, 1927), where an accretionary wedge developed locally during the Early to Middle Devonian (Silva et al., 1990; Eden and Andrews, 1990; Onézime et al., 2002). Afterward, terrigenous sediments and volcanics were deposited in a foredeep basin during the Late Devonian to Middle Carboniferous (Oliveira, 1990), and they deformed closely following deposition, forming a thin-skinned thrust belt (Franke, 2000; Oncken et al., 2000; Onézime et al., 2002). A transform fault might have separated the two parts of the Laurussia-Gondwana plate boundary with opposite subduction polarities.

We begin our cartoon (Fig. 6) at the Early Carboniferous, when the Rheic Ocean had been closed, the northern Gondwana 


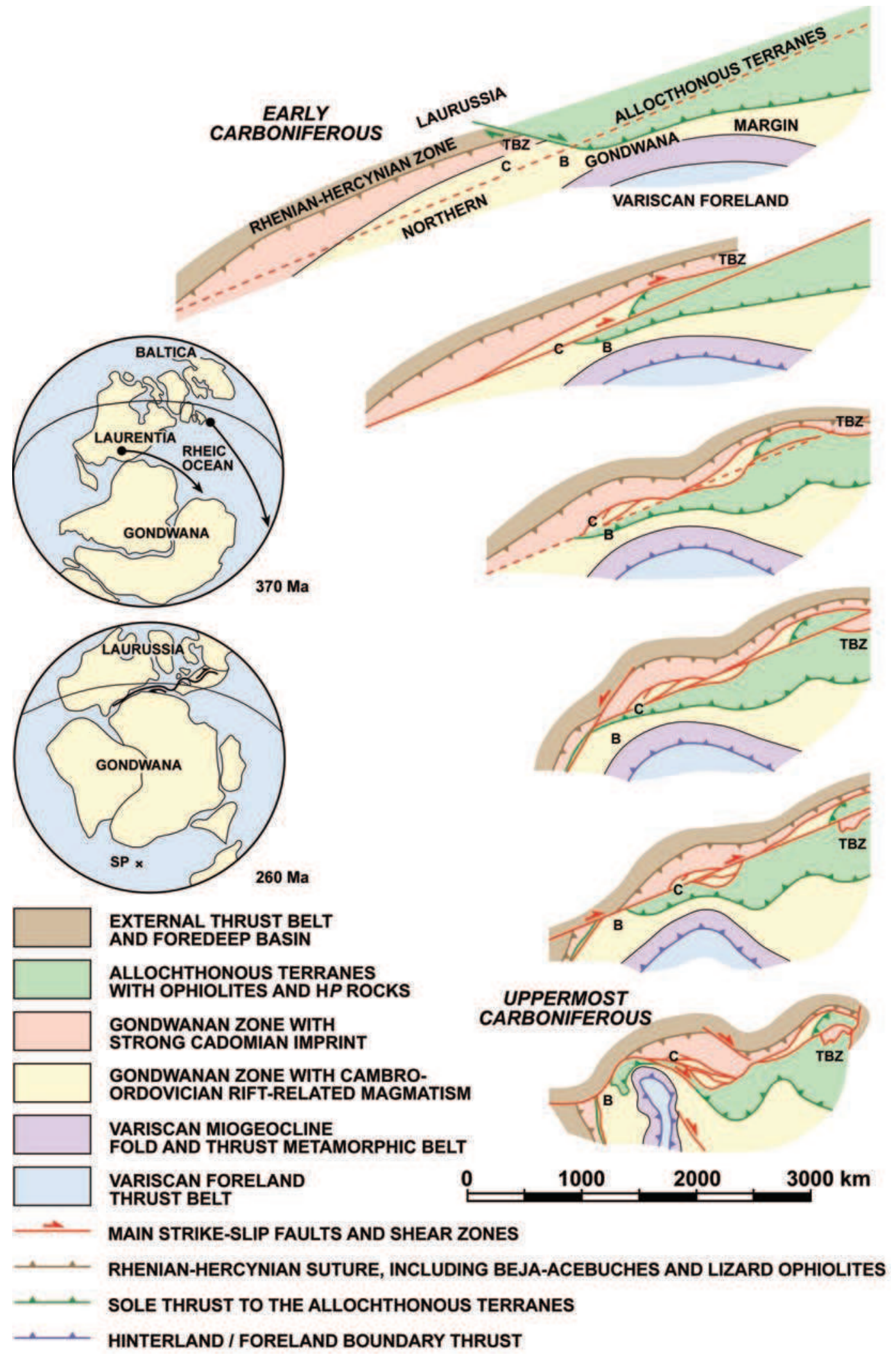

Figure 6. Map view of the proposed evolution of the Variscan belt during the Early and Middle Carboniferous, explaining the different allochthonous terranes as remnants of a huge nappe stack thrust onto the northern platform of Gondwana. Compare with Figure 2 to locate the main massifs and zones and their evolution during strike-slip motion. Note in particular the original neighborhood of Buçaco (B), Crozon (C), and the Teplá-Barrandian zone (TBZ), characterized by similar Paleozoic successions and closely related faunal assemblages. The inset shows the clockwise rotation of Laurentia and Baltica, which provided the convergent component of transpression, and the Carboniferous dextral shearing along the northern margin of Gondwana (after Shelley and Bossière, 2002). 
platform had recorded the early deformation events related to collision, and the allochthonous terranes, including ophiolites and previously subducted rocks, had been obducted onto it. The complexities of this stage were described in a previous section and are sketched in Figure 5. The Rhenian-Hercynian basin had developed already and was the site of synorogenic sedimentation and deformation. This is the starting point of our model in the third dimension, which explains how the allochthonous terranes and the Gondwanan autochthon became subsequently dismembered by strike-slip shear zones and faults that produced $\sim 3000 \mathrm{~km}$ of dextral displacement, and how the Rhenian-Hercynian zone came to be placed to the north of the allochthonous terranes, duplicating the Rheic suture and producing the double vergence characteristic of the Variscan belt.

Probably, wrench components did not appear then for the first time. In fact, dextral transpression has been identified in the Appalachians since the Early Devonian (van Staal and De Roo, 1995), and Late Devonian-Early Carboniferous dextral displacements have been suggested for the central European Variscides by Franke (2000) and for the Armorican Massif by Rolet (1994). It is possible that oblique convergence was active from the beginning of the Variscan cycle, when the Rheic Ocean began to close, and it may have been responsible for the orogen-parallel stretching lineations so common in many allochthonous units (Burg, 1981; Quinquis and Choukroune, 1981; Vauchez and Bufalo, 1988; Ribeiro et al., 1990; Llana-Fúnez, 2002).

The Iberian-Armorican arc has been interpreted as an oroclinal bend that developed from rigid-plastic indentation during collision (Matte, 1986). The arc is rather tight when considering its inner zones, which have a paleogeographic significance (Lotze, 1945; Julivert et al., 1972, 1980). Conversely, it is more open when affecting the main dextral wrench system (PortoTomar dextral shear zone-South Armorican shear zone). Even admitting the existence of a primary open arcuate structure, as indicated by paleomagnetism (Perroud and Bonhommet, 1981; Perroud, 1982; Hirt et al., 1992), Figure 2 suggests that oroclinal bending was coeval with late orogenic stages, and also with the concomitant wrenching. This may explain the sinistral motion of shear zones, which limited the Ossa-Morena zone in the southern branch of the arc, and the formation of fan imbricates and strikeslip duplexes such as those apparently present in the Armorican Massif, which could have formed by the master fault cutting across oroclinal bends (Fig. 6).

The timing of the different steps of the proposed sequence remains imprecise, but the strike-slip activity is bracketed between 345 and $300 \mathrm{Ma}$, the interval of motion of dextral shear zones in the Armorican Massif (Diot et al., 1983; Peucat et al., 1984; Rolet, 1994), which is similar to ages in Iberia, including $342 \mathrm{Ma}$ amphibolite-facies deformation in the BejaAcebuches ophiolitic complex $\left({ }^{40} \mathrm{Ar} /{ }^{39} \mathrm{Ar}\right.$ age; Dallmeyer et al., 1993). It is coeval with or predates sinistral movement, dated at 315-305 Ma for the Porto-Tomar and Juzbado-Penalva shear zones (Rb-Sr ages, Regêncio Macedo, 1988; U-Pb ages, Valle Aguado et al., 2005).
When comparing cross-section and map-view evolution, it is clear that orthogonal shortening and strike slip were active during most of the Carboniferous. This may explain repeated thrusting in northwest Iberia (Fig. 5) and perhaps northwest-directed thrusting of the allochthonous terranes in the Bohemian Massif (Franke, 1989, 2000; Collins et al., 2000). Thrust tectonics reflect the orthogonal component of transpression and tend to hide or delete the traces of previous along-strike components (Johnston, 2001). Therefore, well-preserved strike-slip structures are those formed after thrust and nappe tectonics have ceased in a region. Both orogenic mechanisms reflect a partition of deformation during oblique convergence and may act at the same time, and northwest Iberia is a clear example of such behavior: the PortoTomar and Juzbado-Penalva shear zones (Fig. 2) moved between 315 and 305 Ma (Regêncio Macedo, 1988; Valle Aguado et al., 2005), when thin-skinned tectonics were active in the Cantabrian zone (Fig. 5).

\section{CONCLUSIONS}

The northwestern Iberian Massif offers a clue to understanding the evolution of the Variscan belt, mainly because strike-slip structures are subordinate inside the section, which makes it retrodeformable. A key aspect of the section is the presence of exotic terranes that form a huge and complex allochthonous sheet emplaced upon the sequences deposited on the passive margin of northern Gondwana. The geochemistry of igneous rocks and isotopic age data show that the exotic terranes include parts of a peri-Gondwanan terrane that evolved as a Late Cambrian-Early Ordovician island arc, suprasubduction ophiolites, and pieces of the outermost edge of the Gondwanan continental margin. A precise matching between the ages of metamorphic fabrics and development of large structures has been attempted and the structures have been interpreted in the context of a two-stage evolutionary model consisting of an early Variscan accretionary stage, related to the closure of the Rheic Ocean, followed by a Variscan collisional stage.

Correlation of Iberian allochthonous terranes with those in central European massifs, and also of strike-slip structures along the Variscan belt, have resulted in the elaboration of a transpressional tectonic model for the Variscides that avoids the multiplication of microcontinents and narrow oceanic domains. The model explains the whole belt in terms of the closure of a single ocean, the Rheic, and the subsequent oblique collision between Gondwana and Laurussia. Overprint of a gigantic allochthonous sheet by strike-slip shear zones and faults with a total displacement of $\sim 3000 \mathrm{~km}$ may account for the apparent multiplicity of sutures and peri-Gondwanan terranes.

Given the importance of dextral transpression in the VariscanAppalachian belt, the paleoposition of Iberia along the Gondwanan margin might have been more to the east than suggested by late Paleozoic reconstructions. It is possible that northwest Iberia faced the Tornquist Ocean during the early Paleozoic, that early Variscan deformation was a consequence of Gondwana-Baltica 
convergence, and that the early Variscan accretionary prism preserved in the allochthonous terranes developed in the southern margin of Baltica.

\section{ACKNOWLEDGMENTS}

This contribution has been funded by the Spanish government agency Dirección General de Investigación, through projects BTE2001-0963-C02 and CGL2004-04306-CO2/BTE. The paper has benefited from constructive reviews by R.D. Hatcher Jr., D.T. Secor, and C.R. van Staal, whose criticisms and suggestions are kindly acknowledged.

\section{REFERENCES CITED}

Abati, J., and Dunning, G.R., 2002, Edad U-Pb en monacitas y rutilos de los paragneises de la Unidad de Agualada (Complejo de Ordenes, NW del Macizo Ibérico): Geogaceta, v. 32, p. 95-98.

Abati, J., Dunning, G.R., Arenas, R., Díaz García, F., González Cuadra, P., Martínez Catalán, J.R., and Andonaegui, P., 1999, Early Ordovician orogenic event in Galicia (NW Spain): Evidence from U-Pb ages in the uppermost unit of the Ordenes complex: Earth and Planetary Science Letters, v. 165, p. 213-228, doi: 10.1016/S0012-821X(98)00268-4.

Aleksandrowski, P., and Mazur, S., 2002, Collage tectonics in the northeasternmost part of the Variscan belt: The Sudetes, Bohemian Massif, in Winchester, J.A., Pharaoh, T.C., and Verniers, J., eds., Palaeozoic Amalgamation of Central Europe: Geological Society [London] Special Publication 201, p. 237-277.

Aller, J., and Bastida, F., 1993, Anatomy of the Mondoñedo Nappe basal shear zone (NW Spain): Journal of Structural Geology, v. 15, p. 1405-1419, doi: 10.1016/0191-8141(93)90002-R.

Andonaegui, P., González del Tánago, J., Arenas, R., Abati, J., Martínez Catalán, J.R., Peinado, M., and Díaz García, F., 2002, Tectonic setting of the Monte Castelo gabbro (Ordenes Complex, northwestern Iberian Massif): Evidence for an arc-related terrane in the hanging wall to the Variscan suture, in Martínez Catalán, J.R., Hatcher, R.D., Jr., Arenas, R., and Díaz García, F., eds., VariscanAppalachian Dynamics: The Building of the Late Paleozoic Basement: Geological Society of America Special Paper 364, p. 37-56.

Arenas, R., 1988, Evolución petrológica y geoquímica de la unidad alóctona inferior del complejo metamórfico básico-ultrabásico de Cabo Ortegal (Unidad de Moeche) y del Silúrico paraautóctono, Cadena Hercínica Ibérica (NW de España): A Coruña, Spain, Laboratorio Geológico de Lage, Corpus Geologicum Gallaeciae, v. 4, 543 p.

Arenas, R., and Martínez Catalán, J.R., 2003, Low-P metamorphism following a Barrovian-type evolution: Complex tectonic controls for a common transition, as deduced in the Mondoñedo thrust sheet (NW Iberian Massif): Tectonophysics, v. 365, p. 143-164, doi: 10.1016/S0040-1951(03)00020-9.

Arenas, R., Rubio Pascual, F.J., Díaz García, F., and Martínez Catalán, J.R., 1995, High-pressure micro-inclusions and development of an inverted metamorphic gradient in the Santiago schists (Ordenes Complex, NW Iberian Massif, Spain): Evidence of subduction and syn-collisional decompression: Journal of Metamorphic Geology, v. 13, p. 141-164.

Balé, P., and Brun, J.P., 1986, Les complexes métamorphiques du Léon (NW Bretagne): Un segment du domain éo-Hercynien sud Armoricain translaté au Dévonien: Bulletin de la Société Géologique de France, v. 8, p. 471-477.

Ballèvre, M., Marchand, J., Godard, G., Goujou, J.C., and Wyns, R., 1994, EoHercynian events in the Armorican Massif, structure and metamorphism: The Variscan orogeny in the Armorican Massif, in Keppie, J.D., ed., Pre-Mesozoic Geology in France and Related Areas: Berlin, Germany, Springer-Verlag, p. 183-194.

Bard, J.P., Capdevila, R., and Matte, Ph., 1971, Structure de la chaîne Hercynienne de la Meseta Ibérique: Comparaison avec les segments voisins, in Histoire Structurale du Golfe de Gascogne: Paris, France, Publications de l'Institut Français du Pétrole, Technip, Symposium CNEXO I, v. 4, p. 1-68.

Bastida, F., Marcos, A., Marquínez, J., Martínez Catalán, J.R., Pérez-Estaún, A., and Pulgar, J.A., 1982, Mapa Geológico Nacional, Hoja 1, La Coruña: Madrid, Spain, Instituto Geológico y Minero de España, escala 1:200,000.
Bastida, F., Martínez Catalán, J.R., and Pulgar, J.A., 1986, Structural, metamorphic and magmatic history of the Mondoñedo nappe (Hercynian belt, NW Spain): Journal of Structural Geology, v. 8, p. 415-430, doi: 10.1016/0191-8141(86)90060-X.

Becker, L.P., Frank, W., Höck, V., Kleinschmidt, G., Neubauer, F., Sassi, F.P., and Schramm, J.M., 1987, Outlines of the pre-Alpine metamorphic events in the Austrian Alps, in Flügel, H.V., Sassi, F.P., and Grecula, P., eds., Pre-Variscan and Variscan Events in the Alpine-Mediterranean Mountain Belts: Mineralia Slovaca, Monography: Bratislava, Alfa, p. 69-106.

Behr, H.J., Engel, W., and Franke, W., 1982, Variscan wildflysch and nappe tectonics in the Saxothuringian zone (northeast Bavaria, West Germany): American Journal of Science, v. 282, p. 1438-1470.

Behr, H.J., Engel, W., Franke, W., Giese, P., and Weber, K., 1984, The Variscan belt in Central Europe: Main structures, geodynamic implications, open questions: Tectonophysics, v. 109, p. 15-40, doi: 10.1016/00401951(84)90168-9.

Bellido, F., Brandle, J.L., Lasala, M., and Reyes, J., 1992, Consideraciones petrológicas y cronológicas sobre las rocas graníticas Hercínicas de Galicia: Cuadernos do Laboratorio Xeolóxico de Laxe, v. 17, p. 241-261.

Bourrouilh, R., Cocozza, T., Demange, M., Durand-Delga, M., Gueirard, S., Guitard, G., Julivert, M., Martínez, F.J., Massa, D., Mirouse, R., and Orsini, J.B., 1980, Essai sur l'évolution paléogéographique, structurale et métamorphique du Paléozoïque du Sud de la France et de l'Ouest de la Méditerrané, in 26 Congrés Géologique International, Colloque C6, Géologie de l'Europe: Mémoires du Bureau des Recherches Géologiques et Minières, v. 108, p. 159-188.

Burg, J.P., 1981, Tectonique tangentielle Hercynienne en Vendée littorale: Signification del linéations d'étirement E-W dans les porphyroïdes à foliation horizontale: Comptes Rendus de l'Académie des Sciences Paris, v. 293, p. 849-854.

Burg, J.P., and Matte, Ph., 1978, A cross section through the French Massif Central and the scope of its Variscan geodynamic evolution: Zeitschrift der Deutschen Geologischen Gesellschaft, v. 129, p. 429-460.

Capdevila, R., and Vialette, Y., 1970, Estimation radiométrique de l'âge de la deuxième phase tectonique Hercynienne en Galice Moyenne (nord-ouest de l'Espagne): Comptes Rendus de l'Académie des Sciences Paris, v. 270, p. $2527-2530$.

Castiñeiras, P., 2003, Origen y evolución tectonotermal de las unidades de O Pino y Cariño (Complejos Alóctonos de Galicia) [Ph.D. thesis]: Madrid, Spain, Universidad Complutense, 281 p.

Chantraine, J., Auvray, B., Brun, J.P., Chauvel, J.J., and Rabu, D., 1994, The Cadomian orogeny in the Armorican Massif: Introduction, in Keppie, J.D., ed., Pre-Mesozoic Geology in France and Related Areas: Berlin, Germany, Springer-Verlag, p. 75-80.

Clark, A.H., Scott, D.J., Sandeman, H.A., Bromley, A.V., and Farrar, E., 1998, Siegenian generation of the Lizard ophiolite: U-Pb zircon age data for plagiogranite, Porthkerris, Cornwall: Geological Society [London] Journal, v. 155 , p. $595-598$.

Cocks, L.R.M., and Fortey, R.A., 1988, Lower Palaeozoic facies and faunas around Gondwana, in Audley-Charles, M.G., and Hallam, A., eds., Gondwana and the Tethys: Geological Society [London] Special Publication 37 , p. 183-200.

Cogné, J., 1974, Le Massif Armoricain, in Debelmas, J., ed., Géologie de la France: Paris, Doin, v. 1, p. 105-161.

Cogné, J., 1977, La chaîne Hercynienne ouest-Européenne corespond-elle à un orògene par collision? Propositions pour une interprétation géodynamique globale, in Géologie de l'Himalaya: Paris, France, Colloque International du Centre National de la Recherche Scientifique, v. 268, p. 111-129.

Collins, A.S., Kryza, R., and Zalasiewicz, J., 2000, Macrofabric fingerprints of Late Devonian-Early Carboniferous subduction in the Polish Variscides, the Kaczawa complex, Sudetes: Geological Society [London] Journal, v. 157 , p. $283-288$.

Crespo Blanc, A., 1991, Evolución geotectónica del contacto entre la Zona de Ossa-Morena y la Zona Surportuguesa en las sierras de Aracena y Aroche (Macizo Ibérico meridional): Un contacto mayor de la Cadena Hercínica Europea: Granada, Spain, Facultad de Ciencias, Granada, 328 p.

Crowley, Q.G., Floyd, P.A., Stedrá, V., Winchester, J.A., Kachlík, V., and Holland, J.G., 2002, The Mariánské-Lázne Complex, NW Bohemian Massif: Development and destruction of an early Palaeozoic seaway, in Winchester, J.A., Pharaoh, T.C., and Verniers, eds., Palaeozoic Amalgamation of Central Europe: Geological Society [London] Special Publication 201, p. 177-195. 
Dallmeyer, R.D., and Gil Ibarguchi, J.I., 1990, Age of amphibolitic metamorphism in the ophiolitic unit of the Morais allochthon (Portugal): Implications for early Hercynian orogenesis in the Iberian Massif: Geological Society [London] Journal, v. 147, p. 873-878.

Dallmeyer, R.D., and Tucker, R.D., 1993, U-Pb zircon age for the Lagoa augen gneiss, Morais Complex, Portugal: Tectonic implications: Geological Society [London] Journal, v. 150, p. 405-410.

Dallmeyer, R.D., Ribeiro, A., and Marques, F., 1991, Polyphase Variscan emplacement of exotic terranes (Morais and Bragança Massifs) onto Iberian successions: Evidence from ${ }^{40} \mathrm{Ar} /{ }^{39} \mathrm{Ar}$ mineral ages: Lithos, v. 27 , p. 133-144, doi: 10.1016/0024-4937(91)90025-G.

Dallmeyer, R.D., Fonseca, P., Quesada, C., and Ribeiro, A., 1993, ${ }^{40} \mathrm{Ar} /{ }^{39} \mathrm{Ar}$ mineral age constraints for the tectonothermal evolution of a Variscan suture in southwest Iberia: Tectonophysics, v. 222, p. 177-194, doi: 10.1016/0040-1951(93)90048-O.

Dallmeyer, R.D., Martínez Catalán, J.R., Arenas, R., Gil Ibarguchi, J.I., Gutiérrez Alonso, G., Farias, P., Aller, J., and Bastida, F., 1997, Diachronous Variscan tectonothermal activity in the NW Iberian Massif: Evidence from ${ }^{40} \mathrm{Ar}{ }^{\beta 9} \mathrm{Ar}$ dating of regional fabrics: Tectonophysics, v. 277, p. 307337, doi: 10.1016/S0040-1951(97)00035-8.

Dalziel, I.W.D., 1997, Neoproterozoic-Paleozoic geography and tectonics: Review, hypothesis and environmental speculation: Geological Society of America Bulletin, v. 109, p. 16-42, doi: 10.1130/00167606(1997) 109<0016:ONPGAT>2.3.CO;2.

Dalziel, I.W.D., Dalla Salda, L.H., and Gahagan, L.M., 1994, Paleozoic Laurentian-Gondwana interaction and the origin of the Appalachian-Andean mountain system: Geological Society of America Bulletin, v. 106, p. 243 253, doi: 10.1130/0016-7606(1994)106<0243:PLGIAT > 2.3.CO;2.

Díaz García, F., Arenas, R., Martínez Catalán, J.R., González del Tánago, J., and Dunning, G., 1999, Tectonic evolution of the Careón ophiolite (northwest Spain): A remnant of oceanic lithosphere in the Variscan belt: The Journal of Geology, v. 107, p. 587-605, doi: 10.1086/314368.

Díez Balda, M.A., Martínez Catalán, J.R., and Ayarza, P., 1995, Syn-collisional extensional collapse parallel to the orogenic trend in a domain of steep tectonics: The Salamanca detachment zone (Central Iberian zone, Spain): Journal of Structural Geology, v. 17, p. 163-182, doi: 10.1016/01918141(94)E0042-W.

Diot, H., Bouchez, J.L., and Blaise, J., 1983, La bande ductile Lanvaux-LesPonts-de-Cé entre Redon et Angers. Une composante de cisaillement Hercynien du Massiff Armoricain (France): Bulletin de la Société Géologique de France, v. 7, p. 155-167.

Eden, C.P., and Andrews, J.R., 1990, Middle to Upper Devonian mélanges in SW Spain and their relationship to the Meneage Formation in South Cornwall: Proceedings of the Ussher Society, v. 7, p. 217-222.

Eguíluz, L., Fernández-Carrasco, J., Garrote, A., Liñán, E., and Quesada, C., 1984, Sucesiones estratigráficas del Anticlinorio de Olivenza-Monesterio en la transversal Montemolín- Arroyomolinos: Cuadernos do Laboratorio Xeolóxico de Laxe, v. 8, p. 117-123.

Eguíluz, L., Gil Ibarguchi, J.I., Abalos, B., and Apraiz, A., 2000, Superposed Hercynian and Cadomian orogenic cycles in the Ossa-Morena zone and related areas of the Iberian Massif: Geological Society of America Bulletin, v. 112, p. 1398-1413, doi: 10.1130/0016-7606(2000)112<1398: SHACOC $>2.0 . \mathrm{CO} ; 2$.

Eisbacher, G.H., Lüschen, E., and Wickert, F., 1989, Crustal-scale thrusting and extension in the Hercynian Schwarzwald and Vosges, Central Europe: Tectonics, v. 8, p. 1-21.

Escuder Viruete, J., Arenas, R., and Martínez Catalán, J.R., 1994, Tectonothermal evolution associated with Variscan crustal extension in the Tormes Gneiss Dome (NW Salamanca, Iberian Massif, Spain): Tectonophysics, v. 238, p. 117-138, doi: 10.1016/0040-1951(94)90052-3.

Expósito, I., Simancas, J.F., González Lodeiro, F., Azor, A., and Martínez Poyatos, D.J., 2002, Estructura de la mitad septentrional de la Zona de Ossa-Morena: Deformación en el bloque inferior de un cabalgamiento cortical de evolución compleja: Revista de la Sociedad Geológica de España, v. 15, p. 3-14.

Expósito, I., Simancas, J.F., González Lodeiro, F., Bea, F., Montero, P., and Salman, K., 2003, Metamorphic and deformational imprint of Cambrian-Lower Ordovician rifting in the Ossa-Morena zone (Iberian Massif, Spain): Journal of Structural Geology, v. 25, p. 2077-2087, doi: 10.1016/ S0191-8141(03)00075-0.

Farias Arquer, P., 1990, La geología de la región del Sinforme de Verín (Cordillera Herciniana, NW de España): A Coruña, Spain, Serie Nova Terra, Ediciós do Castro, Sada, v. 2, 201 p.
Farias, P., Gallastegui, G., González-Lodeiro, F., Marquínez, J., Martín Parra, L.M., Martínez Catalán, J.R., de Pablo Maciá, J.G., and Rodríguez Fernández, L.R., 1987, Aportaciones al conocimiento de la litoestratigrafía y estructura de Galicia Central: Memórias da Faculdade de Ciências, Universidade do Porto, v. 1, p. 411-431.

Faure, M., Leloix, C., and Roig, J.Y., 1997, L'évolution polyciclique de la chaîne Hercynienne: Bulletin de la Société Géologique de France, v. 168, p. 695-705.

Fernández-Suárez, J., Dunning, G.R., Jenner, G.A., and Gutiérrez-Alonso, G., 2000a, Variscan collisional magmatism and deformation in NW Iberia: Constraints from $\mathrm{U}-\mathrm{Pb}$ geochronology of granitoids: Geological Society [London] Journal, v. 157, p. 565-576.

Fernández-Suárez, J., Gutiérrez-Alonso, G., Jenner, G.A., and Tubrett, M.N., 2000b, New ideas on the Proterozoic-early Paleozoic evolution of NW Iberia: Insights from U-Pb detrital zircon ages: Precambrian Research, v. 102, p. 185-206, doi: 10.1016/S0301-9268(00)00065-6.

Fernández-Suárez, J., Corfu, F., Arenas, R., Marcos, A., Martínez Catalán, J.R., Díaz García, F., Abati, J., and Fernández, F.J., 2002a, U-Pb evidence for a polyorogenic evolution of the HP-HT units of the NW Iberian Massif: Contributions to Mineralogy and Petrology, v. 143, p. 236-253, doi: 10.1007/s00410-001-0337-2.

Fernández-Suárez, J., Gutiérrez Alonso, G., and Jeffries, T.E., 2002b, The importance of along-margin terrane transport in northern Gondwana: Insights from detrital zircon parentage in Neoproterozoic rocks from Iberia and Brittany: Earth and Planetary Science Letters, v. 204, p. 75-88, doi: 10.1016/S0012-821X(02)00963-9.

Fernández-Suárez, J., Díaz García, F., Jeffries, T.E., Arenas, R., and Abati, J., 2003, Constraints on the provenance of the uppermost allochthonous terrane of the NW Iberian Massif: Inferences from detrital zircon U-Pb ages: Terra Nova, v. 15, p. 138-144, doi: 10.1046/j.1365-3121.2003.00479.x.

Figueiras, J., Mateus, A., Gonçalves, M.-A., Waerenborgh, J., and Fonseca, P., 2002, Geodynamic evolution of the South Variscan Iberian suture as recorded by mineral transformations: Geodinamica Acta, v. 15, p. 45-61, doi: 10.1016/S0985-3111(01)01078-6.

Floor, P., 1966, Petrology of an aegirine-riebeckite gneiss-bearing part of the Hesperian Massif: The Galiñeiro and surrounding areas, Vigo, Spain: Leidse Geologische Mededelingen, v. 36, p. 1-203.

Floyd, P.A., Kryza, R., Crowley, Q.G., Winchester, J.A., and Abdel Wahed, M., 2002, Sleza Ophiolite: Geochemical features and relationship to lower Paleozoic rift magmatism in the Bohemian Massif, in Winchester, J.A., Pharaoh, T.C., and Verniers, J., eds., Palaeozoic Amalgamation of Central Europe: Geological Society [London] Special Publication 201, p. 197-215.

Fonseca, P., and Ribeiro, A., 1993, Tectonics of the Beja-Acebuches ophiolite: A major structure in the Iberian Variscan foldbelt: Geologische Rundschau, v. 82, p. 440-447, doi: 10.1007/BF00212408.

Franke, W., 1989, Tectonostratigraphic units in the Variscan belt of central Europe, in Dallmeyer, R.D., ed., Terranes in the Circum-Atlantic Paleozoic Orogens: Geological Society of America Special Paper 230, p. 67-90.

Franke, W., 2000, The mid-European segment of the Variscides: Tectonostratigraphic units, terrane boundaries and plate tectonic evolution, in Franke, W., Haak, V., Oncken, O., and Tanner, D., eds., Orogenic Processes: Quantification and Modelling in the Variscan Belt: Geological Society [London] Special Publication 179, p. 35-61.

Franke, W., and Zelazniewicz, A., 2002, Structure and evolution of the Bohemian Arc, in Winchester, J.A., Pharaoh, T.C., and Verniers, J., eds., Palaeozoic Amalgamation of Central Europe: Geological Society [London] Special Publication 201, p. 279-293.

Frisch, W., Neubauer, F., and Satir, M., 1984, Concepts of the evolution of the Austroalpine basement complex (eastern Alps) during the CaledonianVariscan cycle: Geologische Rundschau, v. 73, p. 47-68, doi: 10.1007/ BF01820360.

Frisch, W., Neubauer, F., Bröcker, M., Brückmann, W., and Haiss, N., 1987, Interpretation of geochemical data from the Caledonian basement within the Austroalpine basement complex, in Flügel, H.V., Sassi, F.P., and Grecula, P., eds., Pre-Variscan and Variscan Events in the Alpine-Mediterranean Mountain Belts: Mineralia Slovaca, Monography: Bratislava, Alfa, p. 209-226.

Galán, G., and Marcos, A., 1997, Geochemical evolution of high-pressure mafic granulites from the Bacariza Formation (Cabo Ortegal complex, NW Spain): An example of a heterogeneous lower crust: Geologische Rundschau, v. 86, p. 539-555, doi: 10.1007/s005310050162. 
Galán, G., Pin, C., and Duthou, J.L., 1996, Sr-Nd isotopic record of multi-stage interactions between mantle-derived magmas and crustal components in a collision context-The ultramafic-granitoid association from Vivero (Hercynian belt, NW Spain): Chemical Geology, v. 131, p. 67-91, doi: 10.1016/0009-2541(96)00027-7.

García Garzón, J., de Pablo Maciá, J.G., and Llamas Borrajo, J.F., 1981, Edades absolutas obtenidas mediante el método $\mathrm{Rb} / \mathrm{Sr}$ en dos cuerpos de ortoneises en Galicia Occidental: Boletín Geológico y Minero, v. 92, p. 463-466.

Gates, A.E., Simpson, C., and Glover, L., III, 1986, Appalachian Carboniferous dextral strike-slip faults: An example from Brookneal, Virginia: Tectonics, v. 5, p. 119-133.

Gebauer, D., 1993, Intra-grain zircon dating within the Iberian Massif: Ollo de Sapo augengneisses, bimodal gneisses from the Massif de Guilleries (Girona), graywacke of the Tentudía Group (Serie Negra, SW Spain) and the HP/HT-rock association at Cabo Ortegal (Galicia): Évora, Portugal, Comunicações da XII Reunião de Geologia do Oeste Peninsular, Universidade de Évora, v. 2, p. 41-46.

Gil Ibarguchi, J.I., Mendia, M., Girardeau, J., and Peucat, J.J., 1990, Petrology of eclogites and clinopyroxene-garnet metabasites from the Cabo Ortegal Complex (northwestern Spain): Lithos, v. 25, p. 133-162, doi: 10.1016/0024-4937(90)90011-O.

Girardeau, J., Dubuisson, G., and Mercier, J.C., 1994, Igneous activity, Caledono-Hercynian magmatism in the French Massif Central. Early Paleozoic mantle formations. The Limousin ophiolite complexes: Evidence for oceanic lithosphere, in Keppie, J.D., ed., Pre-Mesozoic Geology in France and Related Areas: Berlin, Germany, Springer-Verlag, p. 349-354.

Gómez Barreiro, J., 2004, La Unidad de Fornás: Evolución Tectonometamórfica del SO del Complejo de Órdenes [Ph.D. thesis]: Salamanca, Spain, Universidad de Salamanca, 294 p.

Gómez Barreiro, J., Wijbrans, J.R., Castiñeiras, P., Martínez Catalán, J.R., Arenas, R., Díaz García, F., and Abati, J., 2006, ${ }^{40} \mathrm{Ar} /{ }^{39} \mathrm{Ar}$ laserprobe dating of mylonitic fabrics in a polyorogenic terrane of NW Iberia: Geological Society [London] Journal, v. 163, p. 61-73, doi: 10.1144/0016-764905-012.

Gómez Barreiro, J.G., Martínez Catalán, J.R., Arenas, R., Castiñeiras, P., Abati, J., Díaz García, F., and Wijbrans, J.R., 2007, Tectonic evolution of the upper allochthon of the Órdenes Complex (northwestern Iberian Massif): Structural constraints to a polyorogenic peri-Gondwanan terrane, in Linnemann, U., Nance, R.D., Kraft, P., and Zulauf, G., eds., The Evolution of the Rheic Ocean: From Avalonian-Cadomian Active Margin to Alleghenian-Variscan Collision: Geological Society of America Special Paper 423, p.315-332, doi: 10.1130/2007.2423(15).

González Clavijo, E., and Martínez Catalán, J.R., 2002, Stratigraphic record of preorogenic to synorogenic sedimentation, and tectonic evolution of imbricate units in the Alcañices synform (northwestern Iberian Massif), in Martínez Catalán, J.R., Hatcher, R.D., Jr., Arenas, R., and Díaz García, F., eds., Variscan-Appalachian Dynamics: The Building of the Late Paleozoic Basement: Geological Society of America Special Paper 364, p. 17-35.

González Lodeiro, F., Hernández Urroz, J., Klein, E., Martínez Catalán, J.R., and de Pablo Maciá, J.G., 1981, Mapa Geológico Nacional, Hoja 8, Lugo: Madrid, Spain, Instituto Geológico y Minero de España, escala 1:200,000.

Gutiérrez Marco, J.C., Rábano, I., Sarmiento, G.N., Aceñolaza, G.F., San José, M.A., Pieren, A.P., Herranz, P., Couto, H.M., and Piçarra, J.M., 1999, Faunal dynamics between Iberia and Bohemia during the Oretanian and Dobrotivian (late Middle-earliest Upper Ordovician), and biogeographic relations with Avalonia and Baltica: Acta Universitatis Carolinae-Geologica, v. 43, p. 487-490.

Gutiérrez Marco, J.C., Sarmiento, G.N., Robardet, M., Rábano, I., and Vanek, J., 2001, Upper Silurian fossils of Bohemian type from NW Spain and their palaeogeographical significance: Journal of the Czech Geological Society, v. 46, p. $247-258$.

Hanmer, S.K., 1977, Age and tectonic implications of the Baie d'Audierne basicultrabasic complex: Nature, v. 270, p. 336-338, doi: 10.1038/270336a0.

Hatcher, R.D., Jr., 1989, Tectonic synthesis of the U.S. Appalachians, in Hatcher, R.D., Jr., Thomas, W.A., and Viele, G.W., eds., The Appalachian-Ouachita Orogen in the United States: Boulder, Colorado, Geological Society of America, Geology of North America, v. F-2, p. 511-535.

Hatcher, R.D., Jr., 2002, Alleghanian (Appalachian) orogeny, a product of zipper tectonics: Rotational, transpressive continent-continent collision and closing of ancient oceans along irregular margins, in Martínez Catalán, J.R., Hatcher, R.D., Jr., Arenas, R., and Díaz García, F., eds., VariscanAppalachian Dynamics: The Building of the Late Paleozoic Basement: Geological Society of America Special Paper 364, p. 199-208.
Henry, J.L., Nion, J., Paris, F., and Thadeu, D., 1974, Chitinozoaires, Ostracodes et Trilobites de l'Ordovicien du Portugal (Serra de Buçaco) et du Massif Armoricain: Essai de comparación et signification paléogéographique: Comunicacoes dos Servicos Geologicos de Portugal, v. 57, p. 303-345.

Hirt, A.M., Lowrie, W., Julivert, M., and Arboleya, M.L., 1992, Paleomagnetic results in support of a model for the origin of the Asturian arc: Tectonophysics, v. 213, p. 321-339, doi: 10.1016/0040-1951(92)90461-E.

Hossack, J.R., and Cooper, M.A., 1986, Collision tectonics in the Scandinavian Caledonides, in Coward, M.P., and Ries, A.C., eds., Collision Tectonics: Geological Society [London] Special Publication 19, p. 287-304.

Iglesias Ponce de León, M., and Choukroune, P., 1980, Shear zones in the Iberian arc: Journal of Structural Geology, v. 2, p. 63-68, doi: 10.1016/01918141(80)90035-8.

Johnston, S.T., 2001, The Great Alaskan terrane wreck: Reconciliation of paleomagnetic and geological data in the northern Cordillera: Earth and Planetary Science Letters, v. 193, p. 259-272, doi: 10.1016/S0012$821 \mathrm{X}(01) 00516-7$

Julivert, M., Fontboté, J.M., Ribeiro, A., and Conde, L., 1972, Mapa Tectónico de la Península Ibérica y Baleares: Madrid, Spain, Instituto Geológico y Minero de España, escala 1: 1,000,000.

Julivert, M., Fontboté, J.M., Ribeiro, A., and Conde, L., 1980, Mapa Tectónico de la Península Ibérica y Baleares, Memoria: Madrid, Spain, Instituto Geológico y Minero de España, 113 p.

Kelling, G., Phillips, W.E.A., Harris, A.L., and Howells, M.F., 1985, The Caledonides in the British Isles: A review and appraisal, in Gee, D.G., and Sturt, B.A., eds., The Caledonide Orogen-Scandinavia and Related Areas: New York, John Wiley \& Sons, p. 1125-1146.

Kossmat, F., 1927, Gliederung des varistischen gebirgsbaues: Abhandlungen des Sächsischen Geologischen Landesamtes, v. 1, 39 p.

Kröner, A., and Hegner, E., 1998, Geochemistry, single zircon ages and Sm-Nd systematics of granitoid rocks from the Góry Sowie (Owl Mts.), Polish West Sudetes: Evidence for early Paleozoic arc-related plutonism: Geological Society [London] Journal, v. 155, p. 711-724.

Kuijper, R.P., 1980, Precambrian U-Pb zircon ages from western Galicia (NW Spain): Earth-Science Reviews, v. 16, p. 313-316, doi: 10.1016/00128252(80)90051-3.

Lancelot, J.R., Allegret, A., and Iglesias-Ponce de León, M., 1985, Outline of Upper Precambrian and Lower Paleozoic evolution of the Iberian Peninsula according to U-Pb dating of zircons: Earth and Planetary Science Letters, v. 74, p. 325-337, doi: 10.1016/S0012-821X(85)80004-2.

Ledru, P., Autran, A., and Santallier, D., 1994a, Lithostratigraphy of Variscan terranes in the French Massif Central: A basis for paleogeographical reconstruction, in Keppie, J.D., ed., Pre-Mesozoic Geology in France and Related Areas: Berlin, Germany, Springer-Verlag, p. 276-288.

Ledru, P., Costa, S., and Echtler, H., 1994b, Structure, in Keppie, J.D., ed., Pre-Mesozoic Geology in France and Related Areas: Berlin, Germany, Springer-Verlag, p. 305-323.

Lefort, J.P., 1989, Basement Correlation across the North Atlantic: Berlin, Germany, Springer-Verlag, $148 \mathrm{p}$.

Linnemann, U., and Romer, R.L., 2002, The Cadomian orogeny in SaxoThuringia, Germany: Geochemical and $\mathrm{Nd}-\mathrm{Sr}-\mathrm{Pb}$ isotopic characterization of marginal basins with constraints to geotectonic setting and provenance: Tectonophysics, v. 352, p. 33-64, doi: 10.1016/S00401951(02)00188-9.

Linnemann, U., Elicki, O., and Gaitzsch, B., 2003, Die Stratigraphie das Saxothuringikums: Geologica Saxonica, v. 48/49, p. 29-70.

Llana-Fúnez, S., 2002, Quartz c-axis texture mapping of a Variscan regional foliation (Malpica-Tui Unit, NW Spain): Journal of Structural Geology, v. 24, p. 1299-1312, doi: 10.1016/S0191-8141(01)00138-9.

Lotze, F., 1945, Zur Gliederung der Varisziden der Iberischen Meseta: Geotektonische Forschungen, v. 6, p. 78-92.

Marchand, J., 1981, Ecaillage d'un "mélange tectonique" profond: Le complexe cristallophyllien de Champtoceaux (Bretagne méridionale): Comptes Rendus de l'Académie des Sciences, Paris, v. 293, p. 223-228.

Marcos, A., and Llana Fúnez, S., 2002, Estratigrafía y estructura de la lámina tectónica del para-autóctono y de su autóctono en el área de Chantada (Galicia, NO de España): Trabajos de Geología, Universidad de Oviedo, v. 23 , p. $53-72$.

Marcos, A., Marquínez, J., Pérez-Estaún, A., Pulgar, J.A., and Bastida, F., 1984 Nuevas aportaciones al conocimiento de la evolución tectonometamórfica del Complejo de Cabo Ortegal (NW de España): Cuadernos do Laboratorio Xeolóxico de Laxe, v. 7, p. 125-137. 
Martínez, F.J., Julivert, M., Sebastian, A., Arboleya, M.L., and Gil Ibarguchi, J.I., 1988, Structural and thermal evolution of the high-grade areas in the northwestern parts of the Iberian Massif: American Journal of Science, v. 288, p. 969-996.

Martínez Catalán, J.R., 1990, A non-cylindrical model for the northwest Iberian allochthonous terranes and their equivalents in the Hercynian belt of Western Europe: Tectonophysics, v. 179, p. 253-272, doi: 10.1016/00401951(90)90293-H.

Martínez Catalán, J.R., Arenas, R., Díaz García, F., Rubio Pascual, F.J., Abati, J., and Marquínez, J., 1996, Variscan exhumation of a subducted Paleozoic continental margin: The basal units of the Ordenes Complex, Galicia: NW Spain: Tectonics, v. 15, p. 106-121, doi: 10.1029/95TC02617.

Martínez Catalán, J.R., Díaz García, F., Arenas, R., Abati, J., Castiñeiras, P., González Cuadra, P., Gómez Barreiro, J., and Rubio Pascual, F., 2002, Thrust and detachment systems in the Ordenes Complex (northwestern Spain): Implications for the Variscan-Appalachian geodynamics, in Martínez Catalán, J.R., Hatcher, R.D., Jr., Arenas, R., and Díaz García, F., eds., Variscan-Appalachian Dynamics: The Building of the Late Paleozoic Basement: Geological Society of America Special Paper 364, p. 163-182.

Martínez Catalán, J.R., Arenas, R., and Díez Balda, M.A., 2003, Large extensional structures developed during emplacement of a crystalline thrust sheet: The Mondoñedo nappe (NW Spain): Journal of Structural Geology, v. 25, p. 1815-1839, doi: 10.1016/S0191-8141(03)00038-5.

Martínez Catalán, J.R., Fernández-Suárez, J., Jenner, G.A., Belousova, E., and Díez Montes, A., 2004, Provenance constraints from detrital zircon U$\mathrm{Pb}$ ages in the NW Iberian Massif: Implications for Paleozoic plate configuration and Variscan evolution: Geological Society [London] Journal, v. 161, p. $461-473$

Martínez García, E., 1972, El Silúrico de San Vitero (Zamora): Comparación con las series vecinas e importancia orogénica: Acta Geológica Hispánica, v. 7, p. $104-108$.

Matte, Ph., 1968, La structure de la virgation Hercynienne de Galice (Espagne): Revue de Géologie Alpine, v. 44, p. 157-280.

Matte, Ph., 1986, Tectonics and plate tectonics model for the Variscan belt of Europe: Tectonophysics, v. 126, p. 329-374, doi: 10.1016/00401951(86)90237-4.

Matte, Ph., 1991, Accretionary history and crustal evolution of the Variscan belt in Western Europe: Tectonophysics, v. 196, p. 309-337, doi: 10.1016/0040-1951(91)90328-P.

Matte, Ph., 2002, Variscides, between the Appalachians and the Urals: Similarities and differences between Paleozoic subduction and collision belts, in Martínez Catalán, J.R., Hatcher, R.D., Jr., Arenas, R., and Díaz García, F., eds., Variscan-Appalachian Dynamics: The Building of the Late Paleozoic Basement: Geological Society of America Special Paper 364, p. 237-248.

Mendia Aranguren, M.S., 2000, Petrología de la Unidad Eclogítica del Complejo de Cabo Ortegal (NW de España): A Coruña, Spain, Laboratorio Xeolóxico de Laxe: Nova Terra, v. 16, p. 424.

Ménot, R.P., Peucat, J.J., Scarenzi, D., and Piboule, M., 1988, 496 My age of plagiogranites in the Chamrousse ophiolite complex (external crystalline massifs in the French Alps): Evidence of a Lower Paleozoic oceanization: Earth and Planetary Science Letters, v. 88, p. 82-92, doi: 10.1016/0012821X(88)90048-9.

Nutman, A.P., Green, D.H., Cook, C.A., Styles, M.T., and Holdsworth, R.E., 2001, SHRIMP U-Pb zircon dating of the exhumation of the Lizard Peridotite and its emplacement over crustal rocks: Constraints for tectonic models: Geological Society [London] Journal, v. 158, p. 809-820.

O’Brien, P.J., Corner, A., Jaeckel, P., Hegner, E., Zelazniewicz, A., and Kryza, R., 1997, Petrological and isotopic studies on Paleozoic high pressure granulites, Góry Sowie Mts. Polish Sudetes: Journal of Petrology, v. 38, v. 433-456.

Oliveira, J.T., 1990, South Portuguese zone: Stratigraphy and synsedimentary tectonism, in Dallmeyer, R.D., and Martínez García, E., eds., Pre-Mesozoic Geology of Iberia: Berlin, Springer-Verlag, p. 334-347.

Oliveira, J.T., Horn, M., and Paproth, E., 1979, Preliminary note on the stratigraphy of the Baixo Alentejo Flysch Group, Carboniferous of Portugal, and on the paleogeographic development compared to corresponding units in northwest Germany: Comunicaçoes dos Serviços Geologicos de Portugal, v. 65 , p. $151-168$.

Oncken, O., Plesch, A., Weber, J., Ricken, W., and Schrader, S., 2000, Passive margin detachment arc-continent collision (Central European Variscides), in Franke, W., Haak, V., Oncken, O., and Tanner, D., eds., Orogenic Processes: Quantification and Modelling in the Variscan Belt: Geological Society [London] Special Publication 179, p. 199-216.
Onézime, J., Charvet, J., Faure, M., Chauvet, A., and Panis, D., 2002, Structural evolution of the southernmost segment of the West European Variscides: The South Portuguese zone (SW Iberia): Journal of Structural Geology, v. 24, p. 451-468, doi: 10.1016/S0191-8141(01)00079-7.

Ordóñez Casado, B., Gebauer, D., Schäfer, H.J., Gil Ibarguchi, J.I., and Peucat, J.J., 2001, A single Devonian subduction event for the HP/HT metamorphism of the Cabo Ortegal complex within the Iberian Massif: Tectonophysics, v. 332, p. 359-385, doi: 10.1016/S0040-1951(00)00210-9.

Ortega Cuesta, L.A., 1998, Estudio petrogenético del granito sincinemático de dos micas de A Espenuca (A Coruña): A Coruña, Spain, Serie Nova Terra, Ediciós do Castro, Sada, v. 14, 377 p.

Ortega, L.A., Carracedo, M., Larrea, F.J., and Gil Ibarguchi, J.I., 1996, Geochemistry and tectonic environment of volcanosedimentary rocks from the Ollo de Sapo Formation (Iberian Massif, Spain), in Demaiffe, D., ed., Petrology and Geochemistry of Magmatic Suites of Rocks in the Continental and Oceanic Crusts: Brussels, Belgium, Université Libre de Bruxelles, p. $277-290$

Ortega, L.A., Aranguren, A., Menéndez, M., and Gil Ibarguchi, I., 2000, Petrogénesis, age and emplacement of the late-Hercynian Veiga granite (Ollo de Sapo antiform, northwestern Spain): Cuadernos do Laboratorio Xeolóxico de Laxe, v. 25, p. 265-268.

Paris, F., 1998, Early Palaeozoic palaeobiogeography of northern Gondwana regions: Acta Universitatis Carolinae-Geologica, v. 42, p. 473-483.

Paris, F., and Robardet, M., 1977, Paléogéographie et relations Ibéro-Armoricaines au Paléozoïque anté-Carbonifére: Bulletin de la Société Géologique de France, v. 19, p. 1121-1126.

Pereira, Z., Meireles, C., and Pereira, E., 1999, Upper Devonian palynomorphs of the NE sector of Trás-os-Montes (Central Iberian zone): Badajoz, Spain, XV Reunión de Geología del Oeste Peninsular (International Meeting on Cadomian Orogens, Extended Abstracts), p. 201-206.

Pérez-Estaún, A., 1974, Aportaciones al conocimiento del Carbonífero de San Clodio (Prov. de Lugo): Breviora Geologica Asturica, v. 18, p. 3-8.

Pérez-Estaún, A., Bastida, F., Alonso, J.L., Marquínez, J., Aller, J., AlvarezMarrón, J., Marcos, A., and Pulgar, J.A., 1988, A thin-skinned tectonics model for an arcuate fold and thrust belt: The Cantabrian zone (Variscan Ibero-Armorican arc): Tectonics, v. 7, p. 517-537.

Pérez-Estaún, A., Martínez Catalán, J.R., and Bastida, F., 1991, Crustal thickening and deformation sequence in the footwall to the suture of the Variscan belt of northwest Spain: Tectonophysics, v. 191, p. 243-253, doi: 10.1016/0040-1951(91)90060-6.

Perroud, H., 1982, Contribution à l'étude paléomagnétique de l'arc IbéroArmoricain: Bulletin de la Societé Géologique et Minéralogique de Bretagne, v. 14, p. 1-114

Perroud, H., and Bonhommet, N., 1981, Paleomagnetism of the Ibero-Armorican arc and the Hercynian orogeny in Western Europe: Nature, v. 292, p. 445-448, doi: 10.1038/292445a0.

Peucat, J.J., Auvray, B., Hirbec, Y., and Calvez, J.Y., 1984, Granites et cisaillements Hercyniens dans le Nord du Massif Armoricain: Géochronologie Rb-Sr: Bulletin de la Société Géologique de France, v. 7, p. 1365-1373.

Peucat, J.J., Bernard-Griffiths, J., Gil Ibarguchi, J.I., Dallmeyer, R.D., Menot, R.P., Cornichet, J., and Iglesias Ponce de León, M., 1990, Geochemical and geochronological cross section of the deep Variscan crust: The Cabo Ortegal high-pressure nappe (northwestern Spain): Tectonophysics, v. 177, p. 263-292, doi: 10.1016/0040-1951(90)90285-G.

Pin, C., Ortega Cuesta, L.A., and Gil Ibarguchi, J.I., 1992, Mantle-derived, early Paleozoic A-type metagranitoids from the NW Iberian Massif: Nd isotope and trace-element constraints: Bulletin de la Société Géologique de France, v. 163, p. 483-494.

Pin, C., Paquette, J.L., Santos Zalduegui, J.F., and Gil Ibarguchi, J.I., 2002, Early Devonian supra-subduction zone ophiolite related to incipient collisional processes in the western Variscan belt: The Sierra de Careón unit, Ordenes Complex, Galicia, in Martínez Catalán, J.R., Hatcher, R.D., Jr., Arenas, R., and Díaz García, F., eds., Variscan-Appalachian Dynamics: The Building of the Late Paleozoic Basement: Geological Society of America Special Paper 364, p. 57-72.

Quesada, C., Fonseca, P.E., Munhá, J., Oliveira, J.T., and Ribeiro, A., 1994, The Beja-Acebuches ophiolite (southern Iberia Variscan fold belt): Geological characterization and geodynamic significance: Boletín Geológico y Minero, v. 105 , p. 3-49.

Quinquis, H., and Choukroune, P., 1981, Les schistes bleus de l'Ile de Groix dans la Chaîne Hercynienne: Implications cinématiques: Bulletin de la Société Géologique de France, v. 7, p. 409-418. 
Rast, N., and Skehan, J.W., 1983, The evolution of the Avalonian plate: Tectonophysics, v. 100, p. 257-286, doi: 10.1016/0040-1951(83)90191-9.

Reche, J., Martínez, F.J., Arboleya, M.L., Dietsch, C., and Briggs, W.D., 1998, Evolution of a kyanite-bearing belt within a HT-LP orogen: The case of NW Variscan Iberia: Journal of Metamorphic Geology, v. 16, p. 379-394, doi: 10.1111/j.1525-1314.1998.00142.x.

Regêncio Macedo, C.A., 1988, Granitóides, Complexo Xisto-Grauváquico e Ordovícico na Região Entre Trancoso e Pinhel (Portugal Central) [Ph.D. thesis]: Coimbra, Portugal, Universidade de Coimbra, $430 \mathrm{p}$.

Rey, P., Burg, J.P., and Casey, M., 1997, The Scandinavian Caledonides and their relationship to the Variscan belt, in Burg, J.P., and Ford, M., eds., Orogeny through Time: Geological Society [London] Special Publication 121 , p. $179-200$

Ribeiro, A., 1974, Contribution a l'étude tectonique de Trás-os-Montes Oriental: Memorias dos Serviços Geológicos de Portugal, v. 24, 179 p.

Ribeiro, A., Pereira, E., and Severo, L., 1980, Análise da deformaçao da zona de cisalhamento Porto-Tomar na transversal de Oliveira de Aeméis: Comunicaçoes dos Serviços Geológicos de Portugal, v. 66, p. 3-9.

Ribeiro, A., Pereira, E., and Dias, R., 1990, Central Iberian zone: Allochthonous sequences. Structure in the northwest of the Iberian Peninsula, in Dallmeyer, R.D., and Martínez García, E., eds., Pre-Mesozoic Geology of Iberia: Berlin, Germany, Springer-Verlag, p. 220-236.

Ribeiro, A., Dias, R., and Brandao Silva, J., 1995, Genesis of the Ibero-Armorican arc: Geodinamica Acta, v. 8, p. 173-184.

Ribeiro, M.L., and Floor, P., 1987, Magmatismo peralcalino no Maciço Hespérico: Sua distribução e significado geodinámico, in Bea, F., Carnicero, A., Gonzalo, J.C., López-Plaza, M., and Rodríguez Alonso, M.D., eds., Geología de los Granitoides y Rocas Asociadas del Macizo Hespérico: Madrid, Spain, Rueda, p. 211-221.

Ribeiro, M.L., and Ribeiro, A., 1974, Signification paléogéographique et tectonique de la présence de galets de roches metamorphiques dans un flysch d'âge Dévonien supérieur du Tras-os-Montes oriental (nord-est du Portugal): Comptes Rendus de l'Académie des Sciences, Paris, v. 278, p. 3161-3163.

Riemer, W., 1966, Datos para el conocimiento de la estratigrafía de Galicia: Notas y Comunicaciones del Instituto Geológico y Minero de España, v. 81, p. 7-20.

Ries, A.C., 1979, Variscan metamorphism and K-Ar dates in the Variscan fold belt of S Brittany and NW Spain: Geological Society [London] Journal, v. 136, p. $89-103$.

Robardet, M., 2002, Alternative approach to the Variscan belt of southwestern Europe: Preorogenic paleobiogeographical constraints, in Martínez Catalán, J.R., Hatcher, R.D., Jr., Arenas, R., and Díaz García, F., eds., Variscan-Appalachian Dynamics: The Building of the Late Paleozoic Basement: Geological Society of America Special Paper 364, p. 1-15.

Robardet, M., 2003, The Armorica 'microplate': Fact or fiction? Critical review of the concept and contradictory paleobiogeographical data: Palaeogeography, Palaeoclimatology, Palaeoecology, v. 195, p. 125-148, doi: 10.1016/S0031-0182(03)00305-5.

Robardet, M., and Gutiérrez-Marco, J.C., 2004, The Ordovician, Silurian and Devonian sedimentary rocks of the Ossa-Morena zone (SW Iberian Peninsula, Spain): Journal of Iberian Geology, v. 30, p. 73-92.

Robardet, M., Paris, F., and Racheboeuf, P.R., 1990, Paleogeographic evolution of southwestern Europe during early Paleozoic times, in McKerrow, W.S., and Scotese, C.R., eds., Paleozoic Palaeogeography and Biogeography: Geological Society [London] Memoir 12, p. 411-419.

Rodríguez, J., Cosca, M.A., Gil Ibarguchi, J.I., and Dallmeyer, R.D., 2003, Strain partitioning and preservation of 40Ar/39Ar ages during Variscan exhumation of a subducted crust (Malpica-Tui complex, NW Spain): Lithos, v. 70, p. 111-139, doi: 10.1016/S0024-4937(03)00095-1.

Rolet, J., 1994, Carboniferous tectonics and pull-apart basin development: The Variscan orogeny in the Armorican Massif, structure and metamorphism, in Keppie, J.D., ed., Pre-Mesozoic Geology in France and Related Areas: Berlin, Germany, Springer-Verlag, p. 215-219.

Rolet, J., Gresselin, F., Jegouzo, P., Ledru, P., and Wyns, R., 1994, Intracontinental Hercynian events in the Armorican Massif: The Variscan orogeny in the Armorican Massif, structure and metamorphism, in Keppie, J.D., ed., Pre-Mesozoic Geology in France and Related Areas: Berlin, Germany, Springer-Verlag, p. 195-219.

Román-Berdiel, T., Pueyo-Morer, E.L., and Casas-Sáiz, A.M., 1995, Granite emplacement during contemporary shortening and normal faulting: Structural and magnetic study of the Veiga Massif (NW Spain): Journal of Structural Geology, v. 17, p. 1689-1706, doi: 10.1016/0191-8141(95)00062-I.
Santallier, D., Lardeaux, J.M., Marchand, J., and Marignac, Ch., 1994, Metamorphism: The Massif Central, in Keppie, J.D., ed., Pre-Mesozoic Geology in France and Related Areas: Berlin, Germany, Springer-Verlag, p. 324-340.

Santos Zalduegui, J.F., Schärer, U., and Gil Ibarguchi, J.I., 1995, Isotope constraints on the age and origin of magmatism and metamorphism in the Malpica-Tuy allochthon, Galicia, NW-Spain: Chemical Geology, v. 121, p. 91-103, doi: 10.1016/0009-2541(94)00123-P.

Santos Zalduegui, J.F., Schärer, U., Gil Ibarguchi, J.I., and Girardeau, J., 1996, Origin and evolution of the Paleozoic Cabo Ortegal ultramafic-mafic complex (NW Spain): U-Pb, $\mathrm{Rb}-\mathrm{Sr}$ and $\mathrm{Pb}-\mathrm{Pb}$ isotope data: Chemical Geology, v. 129, p. 281-304, doi: 10.1016/0009-2541(95)00144-1.

Santos, J.F., Schärer, U., Gil Ibarguchi, J.I., and Girardeau, J., 2002, Genesis of pyroxenite-rich peridotite at Cabo Ortegal (NW Spain): Geochemi$\mathrm{cal}$ and $\mathrm{Pb}-\mathrm{Sr}-\mathrm{Nd}$ isotope data: Journal of Petrology, v. 43, p. 17-43, doi: 10.1093/petrology/43.1.17.

Schäfer, H.J., Gebauer, D., Gil Ibarguchi, J.I., and Peucat, J.J., 1993, Ion-microprobe U-Pb zircon dating on the HP/HT Cabo Ortegal Complex (Galicia, NW Spain): Preliminary results: Terra Abstracts, v. 5, no. 4, p. 22.

Scotese, C.R., 2001, Atlas of Earth History: Arlington, Texas, PALEOMAP Project, $52 \mathrm{p}$.

Shelley, D., and Bossière, G., 2000, A new model for the Hercynian orogen of Gondwanan France and Iberia: Journal of Structural Geology, v. 22, p. 757-776, doi: 10.1016/S0191-8141(00)00007-9.

Shelley, D., and Bossière, G., 2002, Megadisplacements and the Hercynian orogen of Gondwanan France and Iberia, in Martínez Catalán, J.R., Hatcher, R.D., Jr., Arenas, R., and Díaz García, F., eds., Variscan-Appalachian Dynamics: The Building of the Late Paleozoic Basement: Geological Society of America Special Paper 364, p. 209-222.

Silva, J.B., Oliveira, J.T., and Ribeiro, A., 1990, South Portuguese zone: Structural outline, in Dallmeyer, R.D., and Martínez García, E., eds., Pre-Mesozoic Geology of Iberia: Berlin, Germany, Springer-Verlag, p. 348-362.

Simancas, F., 2004, Zona Sudportuguesa, estructura, in Vera, J.A., ed., Geología de España: Madrid, Spain, Sociedad Geológica de España-Instituto Geológico y Minero de España, p. 211-214.

Simancas, F., González Lodeiro, F., Expósito Ramos, I., Azor, A., and Martínez Poyatos, D., 2002, Opposite subduction polarities connected by transform faults in the Iberian Massif and western European Variscides, in Martínez Catalán, J.R., Hatcher, R.D., Jr., Arenas, R., and Díaz García, F., eds., Variscan-Appalachian Dynamics: The Building of the Late Paleozoic Basement: Geological Society of America Special Paper 364, p. $249-258$.

Soper, N.J., 1988, Timing and geometry of collision, terrane accretion and sinistral strike-slip events in the British Caledonides, in Harris, A.L., and Fettes, D.J., eds., The Caledonian-Appalachian Orogen: Geological Society [London] Special Publication 38, p. 481-492.

Stampfli, G.M., von Raumer, J.F., and Borel, G.D., 2002, Paleozoic evolution of pre-Variscan terranes: From Gondwana to the Variscan collision, in Martínez Catalán, J.R., Hatcher, R.D., Jr., Arenas, R., and Díaz García, F., eds., Variscan-Appalachian Dynamics: The Building of the Late Paleozoic Basement: Geological Society of America Special Paper 364, p. 263-280.

Stephens, B., and Gee, D.G., 1989, Terranes and polyphase accretionary history in the Scandinavian Caledonides, in Dallmeyer, R.D., ed., Terranes in the Circum-Atlantic Paleozoic Orogens: Geological Society of America Special Paper 230, p. 17-30.

Timmermann, H., Parrish, R.R., Noble, S.R., and Kryza, R., 2000, New U$\mathrm{Pb}$ monazite and zircon data from the Sudetes Mountains: Evidence for a single-cycle Variscan orogeny: Geological Society [London] Journal, v. 157 , p. $265-268$.

Tollman, A., 1982, Großräumiger variszischer Deckenbau im Moldanubikum und neue Gedanken zum Variszikum Europas: Geotektonische Forschungen, v. 64, p. 1-91.

Valle Aguado, B., Azevedo, M.R., Schaltegger, U., Martínez Catalán, J.R., and Nolan, J., 2005, U-Pb zircon and monazite geochronology of Variscan magmatism related to syn-convergence extension in central northern Portugal: Lithos, v. 82, p. 169-184, doi: 10.1016/j.lithos.2004.12.012.

Valverde Vaquero, P., and Dunning, G.R., 2000, New U-Pb ages for Early Ordovician magmatism in Central Spain: Geological Society [London] Journal, v. 157, p. 15-26.

Valverde Vaquero, P., and Fernández, F.J., 1996, Edad de enfriamiento U/Pb en rutilos del Gneis de Chímparra (Cabo Ortegal, NO de España): Geogaceta, v. 20, p. $475-478$ 
Valverde-Vaquero, P., Marcos, A., Farias, P., and Gallastegui, G., 2005, U-Pb dating of Ordovician felsic volcanism in the schistose domain of the Galicia-Trás-os-Montes zone near Cabo Ortegal (NW Spain): Geológica Acta, v. 3, p. 27-37.

Van Calsteren, P.W.C., Boelrijk, N.A.I.M., Hebeda, E.H., Priem, H.N.A., Den Tex, E., Verdurmen, E.A.T.H., and Verschure, R.H., 1979, Isotopic dating of older elements (including the Cabo Ortegal mafic-ultramafic complex) in the Hercynian orogen of NW Spain: Manifestations of a presumed early Paleozoic mantle-plume: Chemical Geology, v. 24, p. 35-56, doi: 10.1016/0009-2541(79)90011-1.

van Staal, C.R., 2005, The northern Appalachians, in Selley, R.C., Cocks, L.R.M., and Plimer, I.R., eds., Encyclopedia of Geology: Oxford, Elsevier, p. 81-91.

van Staal, C.R., and De Roo, J.A., 1995, Mid-Paleozoic tectonic evolution of the Appalachian Central Mobile Belt in northern New Brunswick, Canada: Collision, extensional collapse and dextral transpression, in Hibbard, J.P., van Staal, C.R., and Cawood, P.A., eds., Current Perspectives in the Appalachian-Caledonian Orogen: Geological Association of Canada Special Paper 41, p. 367-389.

van Staal, C.R., Dewey, J.F., MacNiocaill, C., and McKerrow, W.S., 1998, The Cambrian-Silurian tectonic evolution of the northern Appalachians and British Caledonides: History of a complex, west and southwest Pacifictype segment of Iapetus, in Blundell, D.J., and Scott, A.C., eds., Lyell: The Past Is the Key to the Present: Geological Society [London] Special Publication 143, p. 199-242.

Vauchez, A., and Bufalo, M., 1988, Charriage crustal, anatexie et decrochements ductiles dans les Maures orientales (Var, France) au cours de 1'orogenese Varisque: Geologische Rundschau, v. 77, p. 45-62, doi: 10.1007/BF01848675.

Vialette, Y., Casquet, C., Fúster, J.M., Ibarrola, E., Navidad, M., Peinado, M., and Villaseca, C., 1987, Geochronological study of orthogneisses from the Sierra de Guadarrama (Spanish Central System): Neues Jahrbuch für Mineralogie-Monatshefte, v. 10, p. 465-479.

von Raumer, J.F., and Neubauer, F., 1993, Late Precambrian and Paleozoic evolution of the Alpine basement-An overview, in von Raumer, J.F., and
Neubauer, F., eds., Pre-Mesozoic Geology in the Alps: Berlin, Germany, Springer-Verlag, p. 625-639.

von Raumer, J.F., and Neubauer, F., 1994, The Paleozoic evolution of the Alps: Schweizerische Mineralogische und Petrographische Mitteilungen, v. 74, p. $459-467$.

von Raumer, J.F., Stampfli, G.M., Borel, G., and Bussy, F., 2002, Organization of pre-Variscan basement areas at the north-Gondwanan margin: International Journal of Earth Sciences, v. 91, p. 35-52, doi: 10.1007/ s005310100200.

von Raumer, J.F., Stampfli, G.M., and Bussy, F., 2003, Gondwana-derived microcontinents-The constituents of the Variscan and Alpine collisional orogens: Tectonophysics, v. 365, p. 7-22, doi: 10.1016/S00401951(03)00015-5.

Williams, H., and Hatcher, R.D., Jr., 1983, Appalachian suspect terranes, in Hatcher, R.D., Jr., Williams, H., and Zietz, I., eds., The Tectonics and Geophysics of Mountain Chains: Geological Society of America Memoir 158 , p. $33-53$.

Wimmenauer, W., and Lim, S.K., 1988, L'association leptyno-amphibolique de la Forêt-Noire (R.F.A.): Bulletin de la Société Géologique de France, v. 8, p. $35-41$.

Winchester, J.A., Pharaoh, T.C., and Verniers, J., 2002, Palaeozoic amalgamation of Central Europe: An introduction and synthesis of new results from recent geological and geophysical investigations, in Winchester, J.A., Pharaoh, T.C., and Verniers, J., eds., Palaeozoic Amalgamation of Centra Europe: Geological Society [London] Special Publication 201, p. 1-18.

Young, T.P., 1990, Ordovician sedimentary facies and faunas of southwest Europe: Palaeogeographic and tectonic implications, in McKerrow, W.S., and Scotese, C.R., eds., Palaeozoic Palaeogeography and Biogeography: Geological Society [London] Memoir 12, p. 421-430. 